\title{
Nitric Oxide Removal from Flue Gas by Combined Persulfate and Ferrous-EDTA Solutions: Effects of Persulfate and EDTA Concentrations, Temperature, $\mathrm{pH}$ and $\mathrm{SO}_{2}$
}

\author{
Yusuf G. Adewuyi*and M. Arif Khan
}

Chemical, Biological and Bio Engineering Department, North Carolina Agricultural and Technical State University Greensboro, NC 27411 USA

*Correspondence: Phone (336) 285-3651; Fax: (336) 334-7417; E-mail: $\underline{\text { adewuyi@ncat.edu }}$

ABSTRACT: The effects of persulfate (PS) and ethylenediaminetetraacetate (EDTA)

concentrations at different temperature and $\mathrm{pH}$ on the removal of $\mathrm{NO}$ were studied using combined $\mathrm{Na}_{2} \mathrm{~S}_{2} \mathrm{O}_{8}$ and $\mathrm{Fe}^{2+}$-EDTA aqueous solutions. The experiments were conducted in the temperature and $\mathrm{pH}$ ranges of $23-70{ }^{\circ} \mathrm{C}$ and $2-12$, respectively, using $0.05-0.20 \mathrm{M}$ PS and 0.01 $\mathrm{MFe}^{2+}$ in the absence and presence of $0.005-0.050 \mathrm{M} \mathrm{Na}$-EDTA. The effect of $\mathrm{SO}_{2}$ was also preliminarily investigated. Increased temperature led to increased conversions of NO (percent inlet NO removed) at all PS levels but high concentrations of EDTA produced antagonistic effects with increasing temperature. With $0.10 \mathrm{M} \mathrm{Na}_{2} \mathrm{~S}_{2} \mathrm{O}_{8}, 0.01 \mathrm{M} \mathrm{Fe}^{2+}$ and $\leq 0.01 \mathrm{M}$ EDTA, NO conversion increased with temperature from 23 to $70^{\circ} \mathrm{C}$. At $70^{\circ} \mathrm{C}$, NO conversion increased from 83.40 to $96.28 \%$ as EDTA concentration increased from 0.005 to 0.01 M EDTA but decreased to 29.22 and $0.4 \%$ with 0.02 and 0.05 M EDTA, respectively. The results at 40 and 50 ${ }^{\circ} \mathrm{C}$ showed optimal $\mathrm{NO}$ conversions in the $\mathrm{pH}$ range $6-8$, and higher at $50^{\circ} \mathrm{C}$. However, at higher $\mathrm{pH}(>11)$, NO conversion is higher at $40^{\circ} \mathrm{C}$ than at $50^{\circ} \mathrm{C}$. The speciation and material balance of the iron species were determined at different $\mathrm{Fe}^{2+}$ and EDTA concentrations. The results, which showed sustained NO absorption at lower temperatures and mid-pH, could in practice minimize process $\mathrm{pH}$ adjustment and energy usage in wet scrubbers. The process could be applicable to the simultaneous cleanup of $\mathrm{NO}_{\mathrm{x}}$ and $\mathrm{SO}_{2}$ from oil- and coal-fired power plant and industrial boiler. 
Keywords: Nitric Oxide; Absorption; Oxidation; Persulfate, Ferrous-EDTA; Activation.

\section{Introduction}

The three primarily energy sources for generating electric power are coal, natural gas, and nuclear energy. $\mathrm{NO}_{\mathrm{x}}$ (mainly $\mathrm{NO}_{2}$ and $\mathrm{NO}$ ) and $\mathrm{SO}_{2}$ released from the combustion of coal, fuel oils and solid waste have significant impact on the health of humans and ecosystems. $[1,2]$ Stringent environmental laws and regulations have driven recent advances in air emission control technologies.[3] The U.S. Environmental Protection Agency (EPA), for example, established the Acid Rain Program (ARP) and Cross-State Air Pollution Rule (CSAPR) to curb $\mathrm{SO}_{2}$ and $\mathrm{NO}_{\mathrm{x}}$ emissions from thermal power plants.[4] Wet flue gas desulfurization (WFGD) and selective catalytic reduction (SCR) are deployed for the abatement of $\mathrm{SO}_{2}$ and $\mathrm{NO}_{\mathrm{x}}$ emissions, respectively.[5] It is well known that SCR has high capital and operational costs and large environmental footprint, and usually operates at high temperatures (200-400 ${ }^{\circ} \mathrm{C} .[6]$ One motivation behind wet scrubbing is to retrofit existing WFGD scrubber system to provide simultaneous multicomponent ( $\mathrm{SO}_{2}, \mathrm{NO}_{\mathrm{x}}$ and mercury) control, thereby lowering costs, along with smaller plant footprint.[7, 8] Therefore, processes using wet scrubbing agents such as strong oxidants and metal chelates, and for which existing plants can be retrofitted for multiple applications are emerging. [9-11] Results from some recent studies have demonstrated that the use of $\mathrm{UV} / \mathrm{H}_{2} \mathrm{O}_{2}$ and $\mathrm{UV} /$ Fenton-like reacting systems are also effective for the simultaneous removal of $\mathrm{NO}$ and $\mathrm{SO}_{2}$.[12-14] In China, where there is a great dependence on coal as energy source, such processes for flue gas cleanup are gaining significant popularity.[15] These methods either involve the conversion of $\mathrm{NO}$ and $\mathrm{SO}_{2}$ into soluble $\mathrm{NO}_{2}$ and $\mathrm{SO}_{3}$, followed by absorption to form sulfuric and nitric acids and/or sulfates and nitrates, respectively, or coordination of NO with metal complexes to quickly form nitrosyls followed by liquid treatment.[16] 
Adewuyi and coworkers reported the use of aqueous sodium persulfate $\left(\mathrm{Na}_{2} \mathrm{~S}_{2} \mathrm{O}_{8}\right)$ activated by temperature only or with $\mathrm{Fe}^{2+}$ for both $\mathrm{NO}$ only and simultaneous $\mathrm{NO} / \mathrm{SO}_{2}$ removal, and commented on its safety, stability and environmental benign nature.[17-20] The persulfate (PS) or peroxydisulfate anion $\left(\mathrm{S}_{2} \mathrm{O}_{8}{ }^{2-}\right)$ is a strong and non-selective oxidant $\left(\mathrm{E}^{\mathrm{o}}=2.01 \mathrm{~V}\right)$ comparable to $\mathrm{O}_{3}$ and $\mathrm{H}_{2} \mathrm{O}_{2}$, both of which are widely used in waste treatment.[21-24]

$\mathrm{S}_{2} \mathrm{O}_{8}^{2-}+2 e^{-} \rightarrow 2 \mathrm{SO}_{4}^{2-}, \quad \mathrm{E}^{\circ}=2.01 \mathrm{~V}$

However, it is kinetically slow at ordinary conditions and often activated by high/alkaline $\mathrm{pH}$, heat, light, ultrasound or transition metal ions such as Fe(II) (or its chelate complexes) to generate intermediate sulfate free radical $\left(\mathrm{SO}_{4}^{--}\right)$as represented by eq 2 and eq 3 , respectively.[25]

$\mathrm{S}_{2} \mathrm{O}_{8(a q)}^{2-}+$ heat/UV/Ultrasound $\quad \rightarrow 2 \mathrm{SO}_{4}^{\cdot-}$

$\mathrm{S}_{2} \mathrm{O}_{8}^{2-}+\mathrm{Me}_{(\mathrm{aq})}^{n+} \rightarrow \mathrm{SO}_{4(\mathrm{aq})}^{--}+\mathrm{SO}_{4(\mathrm{aq})}^{2-}+\mathrm{Me}_{(\mathrm{aq})}^{(n+1)+}$

The decomposition reactions of $\mathrm{S}_{2} \mathrm{O}_{8}{ }^{2-}$ also vary with $\mathrm{PS}$ concentration, $\mathrm{pH}$, and $\mathrm{O}_{2}$, and $\mathrm{H}_{2} \mathrm{O}_{2}$ or peroxymonosulfate (PMS) can be produced.[26] The thermal and $\mathrm{Fe}^{2+}$ ion activation of $\mathrm{S}_{2} \mathrm{O}_{8}{ }^{2-}$ leads to the production of $\mathrm{SO}_{4}{ }^{--}$, which is responsible for the production of $\mathrm{OH}^{\bullet}$ that acts as the main oxidant for the conversion of NO.[20, 27]

The use of chelated ferrous ethylenediaminetetraacetic acid $\left(\mathrm{Fe}^{2+}-\mathrm{EDTA}\right)$ for $\mathrm{NO}$ removal has been extensively reported in the literature, where NO is combined with $\mathrm{Fe}^{2+}-\mathrm{EDTA}$ by reversible binding and separated from the solution.[11, 28-32] Although Fe $^{2+}$-EDTA can obtain a high $\mathrm{NO}$ removal efficiency, it is easily oxidized (by $\mathrm{NO}, \mathrm{NO}_{2}$ and $\mathrm{O}_{2}$ in the flue gas) to $\mathrm{Fe}^{3+}-$ EDTA that is not capable of binding NO. As a result, the concentration of the active 
$\mathrm{Fe}^{2+}$-EDTA in the scrubbing solutions decreases quickly with significant loss of NO absorption capability as early as 2-3 h.[28] Hence, the main drawbacks of this process include removal of the $\mathrm{Fe}^{2+}-\mathrm{EDTA}(\mathrm{NO})$ complex formed, fast oxidation of $\mathrm{Fe}^{2+}-\mathrm{EDTA}$ to the inert $\mathrm{Fe}^{3+}$-EDTA and high cost of EDTA. It has also been suggested that both $\mathrm{Fe}^{2+}$-EDTA and $\mathrm{Fe}^{3+}$-EDTA can also activate the PS anion, thus producing a complete synergistic relationship with the PS.[33] Recently, Adewuyi and Khan (2015), for the first time, studied the effect of combined PS and ferrous EDTA reaction systems on NO removal, using 0.1 M PS and $0.01 \mathrm{Fe}^{2+}$. [25] The results showed that the presence of EDTA improved and sustained NO removal significantly compared with temperature-only and combined temperature- $\mathrm{Fe}^{2+}$ activated PS systems. Also, issues relating to spent solution regeneration, reaction products and conversion to benign or useful endproducts, were discussed.[25] The proposed pathways for the $\mathrm{NO}_{\mathrm{x}}-\mathrm{S}_{2} \mathrm{O}_{8}-\mathrm{Fe}^{2+}-\mathrm{EDTA}$ system are depicted in Scheme 1. In this study, the goal was to understand the chemistry of the combined $\mathrm{Na}_{2} \mathrm{~S}_{2} \mathrm{O}_{8}$ and $\mathrm{Fe}^{2+}$-EDTA process at wider ranges of concentrations of $\mathrm{PS}$ and $\mathrm{Fe}^{2+}$ for different concentrations of EDTA, without the complexity introduced by the presence of $\mathrm{O}_{2}$. The combinative effects of initial PS and EDTA concentrations, temperature and $\mathrm{pH}$ on $\mathrm{NO}$ conversion were studied to elucidate the interactive, synergistic and/or antagonistic relationships of these process parameters. The longtime viability of the absorbent solution was also evaluated, and implication of the study to energy and process applications discussed. The speciation and material balance of iron species $\left(\mathrm{Fe}^{2+}, \mathrm{Fe}^{3+}\right.$ and $\mathrm{Fe}^{2+}$-EDTA) were determined at the different $\mathrm{Fe}^{2+}$ and EDTA concentrations to further evaluate the process chemistry. The effect of $\mathrm{SO}_{2}$ on NO removal was also preliminarily investigated. This study should be useful for future scale-up and application to low-temperature, and hence, reduced-energy treatment of $\mathrm{NO}_{\mathrm{x}}$ and $\mathrm{SO}_{2}$ from oil/coal-fired power or steel plants, incinerators, combustors and industrial boilers. 


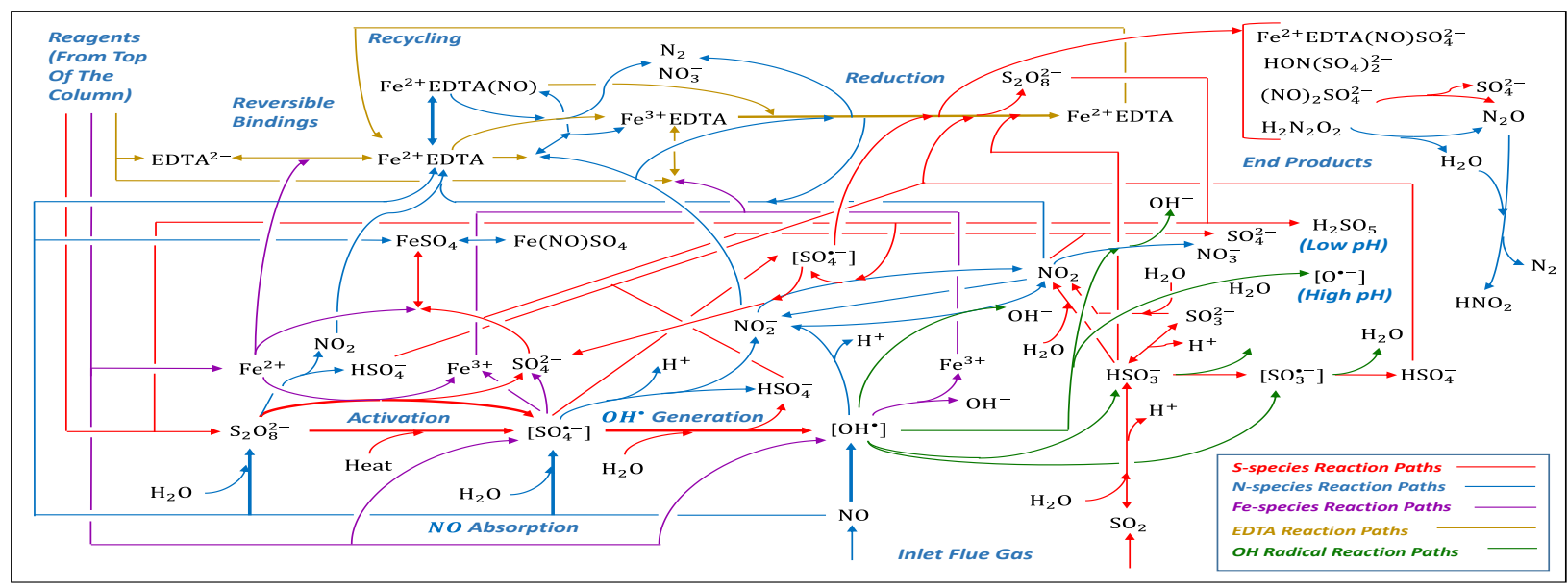

Scheme 1: Schematic diagram of the NO-PS-Fe $e^{2+}$ EDTA reacting systems

\section{Experimental}

2.1. Materials. Sodium persulfate (powder, >98\%), iron (II) sulfate heptahydrate $\left(\mathrm{FeSO}_{4} .7 \mathrm{H}_{2} \mathrm{O},>99 \%\right)$, concentrated sulfuric acid $(95-98 \%)$ and $1.0 \mathrm{~N}$ sodium hydroxide solution were obtained from Acros Organics, Morris Plains, NJ; disodium ethylenediaminetetraacetate (Na2-EDTA, reagent grade), and sodium hydroxide (solid) were obtained from Fisher Chemical, Fair Lawn, NJ; and 5.0 N sulfuric acid from LabChem Inc., Pittsburg, PA. Ultrahigh purity (5.0grade) nitrogen $\left(\mathrm{N}_{2}\right)$ and $\mathrm{NO} / \mathrm{SO}_{2}$ mixtures in ultrapure (4.8-grade) $\mathrm{N}_{2}$ were obtained from Airgas National Welders, Charlotte, NC. Deionized water was obtained from a Milli-Q Advantage A 10 purifier with Elix 5 system from Millipore Corporation, Bedford, MA. The water had a resistivity of at least $18.2 \mathrm{M} \Omega . \mathrm{cm}$, and the total organic contents, silicates and heavy metals contents were reduced very low parts per billion (ppb) levels.

2.2. Methods. The schematic diagram for the $\mathrm{NO}$ absorption consisted of a thermally jacketed bubble column reactor made of Pyrex glass $(5.1 \mathrm{~cm}$ i.d. $\times 61-\mathrm{cm}$ length designed inhouse and custom-built by Ace Glass, Inc., Vineland, NJ), flue gas blending system consisting of a Dynablender mass flow controller (Matheson Tri-gas, Montgomeryville, PA) with two flow transducer calibrated to allow a maximum flow of 5 standard liters per minute (SLPM) gas, and 
analytical train of Fourier Transform Infrared (FTIR) spectrometer (Tensor 27; Bruker Optics, Billerica, MA). The temperature setting was maintained by circulating water through the jacketed column using the cooling/heating system of a refrigerated bath (Neslab RTE7D1, Thermo Scientific, Newington, NH). The scrubber was operated in a semibatch mode with the simulated gas flowing upward continuously at a rate of 0.1 SLPM. The column was initially filled with $750 \mathrm{ml}$ of water and $\mathrm{N}_{2}$ was passed through it for $15 \mathrm{~min}$ to purge it of dissolved oxygen. Freshly prepared $\mathrm{Fe}^{2+}$, EDTA and PS solutions of appropriate quantity to make $1.0 \pm$ $0.05 \mathrm{~L}$ total volume of solution (corresponding to a liquid height of $\sim 0.5 \mathrm{~m}$ ) of desired concentration were added to the water consecutively at the top of the column, previously determined to be the best injection method from a previous study.[19] The experimental setup is shown in Figure 1 and is discussed in detail elsewhere.[10, 17, 25] $\mathrm{NO}_{\mathrm{x}}$ and $\mathrm{SO}_{2}$ concentrations in the outlet gas were continuously monitored and recorded by proprietary software, Enformatic FTIR Collection Manager (EFCM) from FTIR.com. The solution $\mathrm{pH}$ was monitored continuously, and the initial and final $\mathrm{pH}$ also recorded using Accumet $\mathrm{pH}$ meter 50 (Thermo Scientific) and $\mathrm{pH}$ semi micro tip probe (Orion $8103 \mathrm{BN}$ ). Liquid samples of 10-15 mL were taken quickly from the side syringe of the reactor into a number of small test tubes as soon as 30 $\mathrm{s}$ and at subsequent allowable intervals for up to about $1 \mathrm{~h}$. The details of the analytical procedures, including iron speciation $\left(\mathrm{Fe}^{2+}, \mathrm{Fe}^{3+}\right.$ and $\mathrm{Fe}^{2+}$-EDTA), analysis of gas-phase $\mathrm{NO}_{\mathrm{x}}$ and anions (oxidation products of mainly $\mathrm{NO}_{3}{ }^{-}$and not $\mathrm{NO}_{2}{ }^{-}$), and material balances in solution, are reported in previous studies.[17, 25, 34]

Several sets of experiments at various temperatures $\left(23,30,40,50,60\right.$ and $70\left( \pm 1{ }^{\circ} \mathrm{C}\right)$, and acidic to alkaline $\mathrm{pH}(\mathrm{pH} 2.0-12.0)$ were conducted to investigate the removal of NO (753 ppm initial gas-phase, typical average of industrial flue gases) using aqueous solutions 
containing $\mathrm{Na}_{2} \mathrm{~S}_{2} \mathrm{O}_{8}(0.05,0.10$, and $0.2 \mathrm{M}( \pm 0.5 \%))$ and $\mathrm{Fe}^{2+}(0.01 \mathrm{M}( \pm 0.5 \%))$ in the absence and presence of Na2-EDTA $(0.005,0.01,0.02$, and $0.05 \mathrm{M}( \pm 0.5 \%))$.

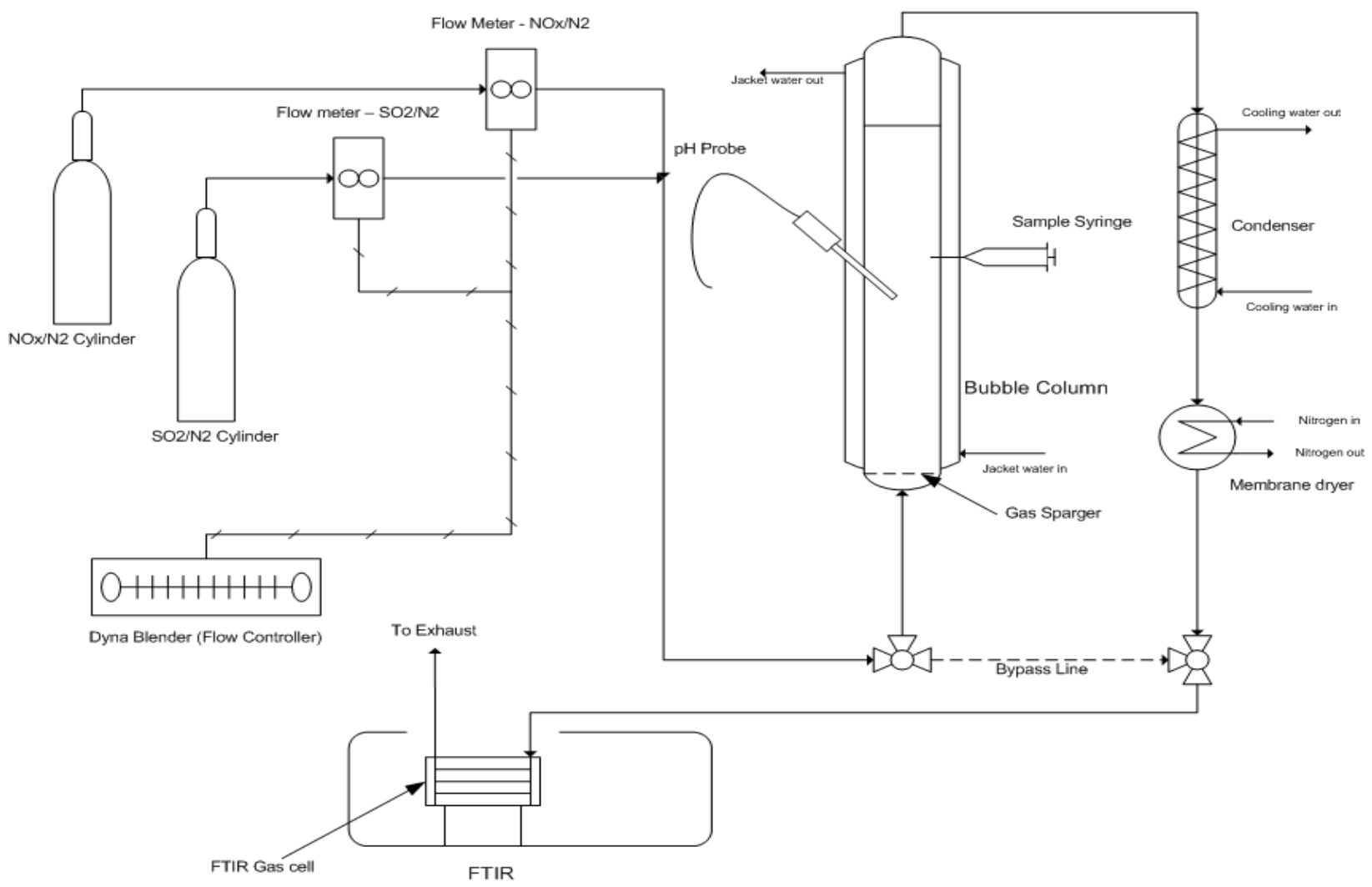

Figure 1. Schematic diagram of the experimental set-up

From the FTIR's EFCM recorded data, outlet gas concentration-time profiles were obtained and fractional percent conversion of NO obtained from,

$\mathrm{X}_{\mathrm{NO}}=\frac{[\mathrm{NO}]_{\text {in }}-[\mathrm{NO}]_{\text {out }}}{[\mathrm{NO}]_{\text {in }}} \times 100 \%$

where $[\mathrm{NO}]_{\text {in }}$ and $[\mathrm{NO}]_{\text {out }}$ are the steady state concentration in parts per million (ppm) of NO at the inlet and outlet of the reactor, respectively. [NO $]_{\text {out }}$ was calculated by averaging the values of the outlet concentration after 3000 s. It should be noted that the concentration-time profiles show the characteristic initial sharp drop in NO exit concentration due to absorption in unsaturated solutions, and mixing and dilution effects of the purge gas (i.e., $\mathrm{N}_{2}$ filling the void above the liquid level in the column), which was also previously observed and discussed.[9, 10, 17] 


\section{Results and Discussion}

\subsection{Effects of $\mathrm{Na}_{2} \mathrm{~S}_{2} \mathrm{O}_{8}$ Concentrations and Temperature on NO Removal.}

The influence of three PS concentration levels $(0.05,0.10$, and $0.20 \mathrm{M})$ on NO concentration profiles in the presence of $0.01 \mathrm{M} \mathrm{Fe}^{2+}$ and $0.01 \mathrm{M}$ EDTA at various temperatures $(23,30,40$, 50, 60 and $70{ }^{\circ} \mathrm{C}$ ) is shown in Figure 2. The effects of temperature and PS concentration on the steady state conversion of $\mathrm{NO}$ (at time $\geq 3000 \mathrm{~s}$ ) in the presence of $0.01 \mathrm{M} \mathrm{Fe}^{2+}$ and $0.01 \mathrm{M}$ EDTA are illustrated in Figure 3. The NO conversion as a function of PS concentration for all temperatures up to $70{ }^{\circ} \mathrm{C}$ illustrated on Figure 3(a) indicates that, in general, conversion at all temperatures increases with PS up to $0.10 \mathrm{M}$, before appearing to level off. In addition, increased temperature led to increased conversion of NO at all PS concentration levels. Figure 3(b) shows the NO conversion as a function of temperature for the different PS concentrations in the presence of $0.01 \mathrm{M} \mathrm{Fe}^{2+}$ and $0.01 \mathrm{M}$ EDTA. As shown in this figure, in general, NO conversion increases with temperature at all PS levels, with the marginal change in NO conversion more significant, going from 0.05 to $0.1 \mathrm{M}$ but diminishing beyond $0.1 \mathrm{M}$. For example, the conversions were found to be $92.4 \%, 95.4 \%$ and $97.3 \%$ at $70{ }^{\circ} \mathrm{C}$ respectively, for $0.05,0.1$ and $0.2 \mathrm{M}$ PS compared with $67.7 \%, 77.2 \%$ and $78.2 \%$ at $50{ }^{\circ} \mathrm{C}$ and $42.8 \%, 48.5 \%$ and $51.5 \%$ at 23 ${ }^{\circ} \mathrm{C}$, for the same PS concentration levels.

As summarized in Table 1 (reactions R1-R50) and in Scheme 1, the PS oxidation chemistry of $\mathrm{NO}$ in the presence of $\mathrm{Fe}^{2+}$-EDTA is complex, since it takes place through direct electron transfer from the PS anion, and free radical reactions via the sulfate radical generated by activation (R5-R10), and the direct reaction of the $\mathrm{NO}_{\mathrm{x}}$ species with $\mathrm{Fe}^{2+}$-EDTA, which results from the reversible reaction of $\mathrm{Fe}^{2+}$ and $\mathrm{EDTA}^{2-}$. Hence, the removal of the NO is also thought to 
be dependent on the consumption of the dissolved NO by the various reactive species in the liquid phase, which maintains the driving force needed for the absorption process.
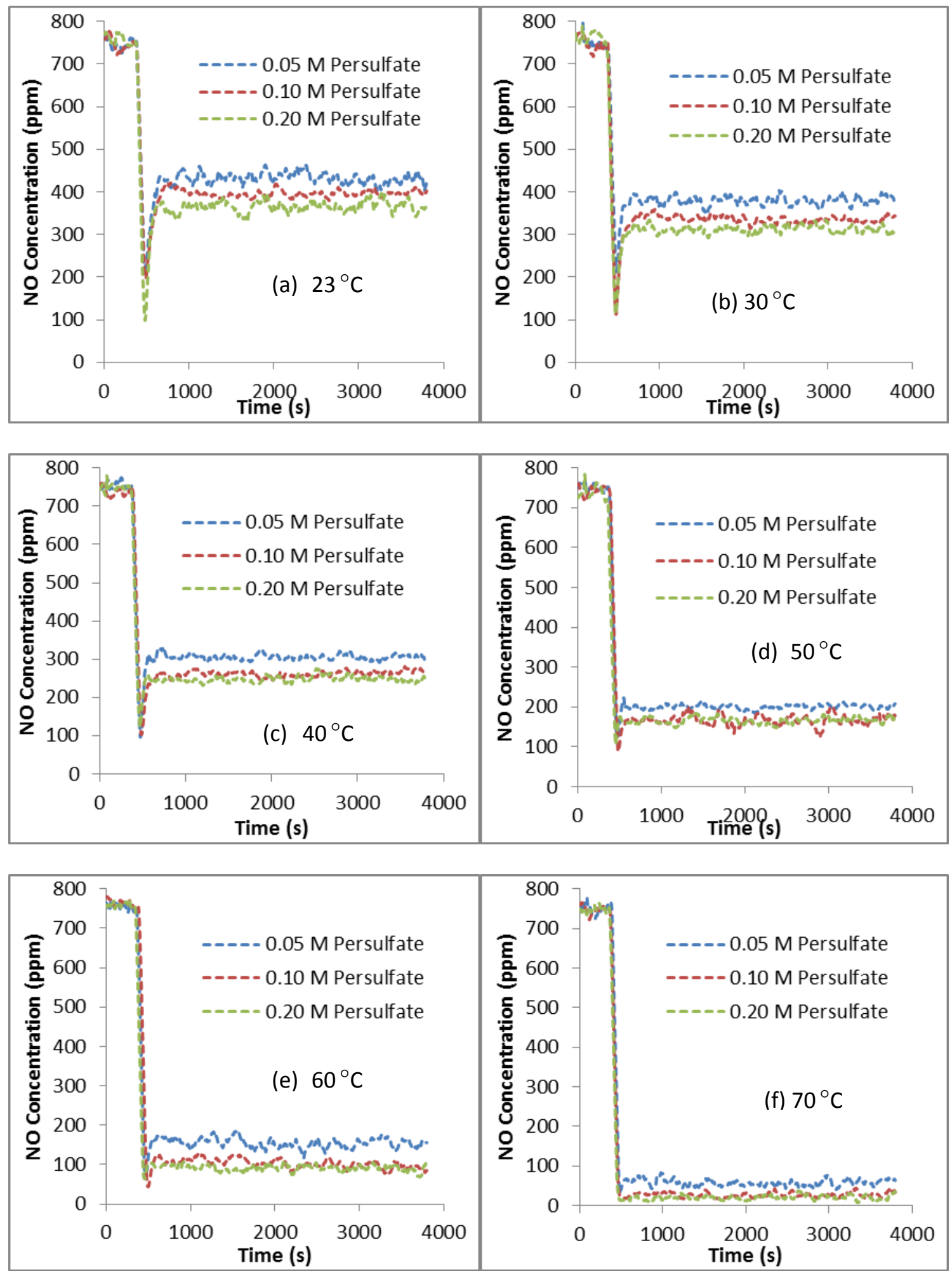
Figure 2. $\mathrm{NO}$ concentration profiles for different initial $\mathrm{Na}_{2} \mathrm{~S}_{2} \mathrm{O}_{8}$ concentrations $(0.05,0.10$ and $0.20 \mathrm{M})$ with $0.01 \mathrm{M} \mathrm{Fe}^{2+}$ and $0.01 \mathrm{M} \mathrm{Na} 2$-EDTA at various temperatures $\left(23-70{ }^{\circ} \mathrm{C}\right):(a) 23$, (b) 30, (c) 40, (d) 50, (e) 60 and (f) $70^{\circ} \mathrm{C}$.
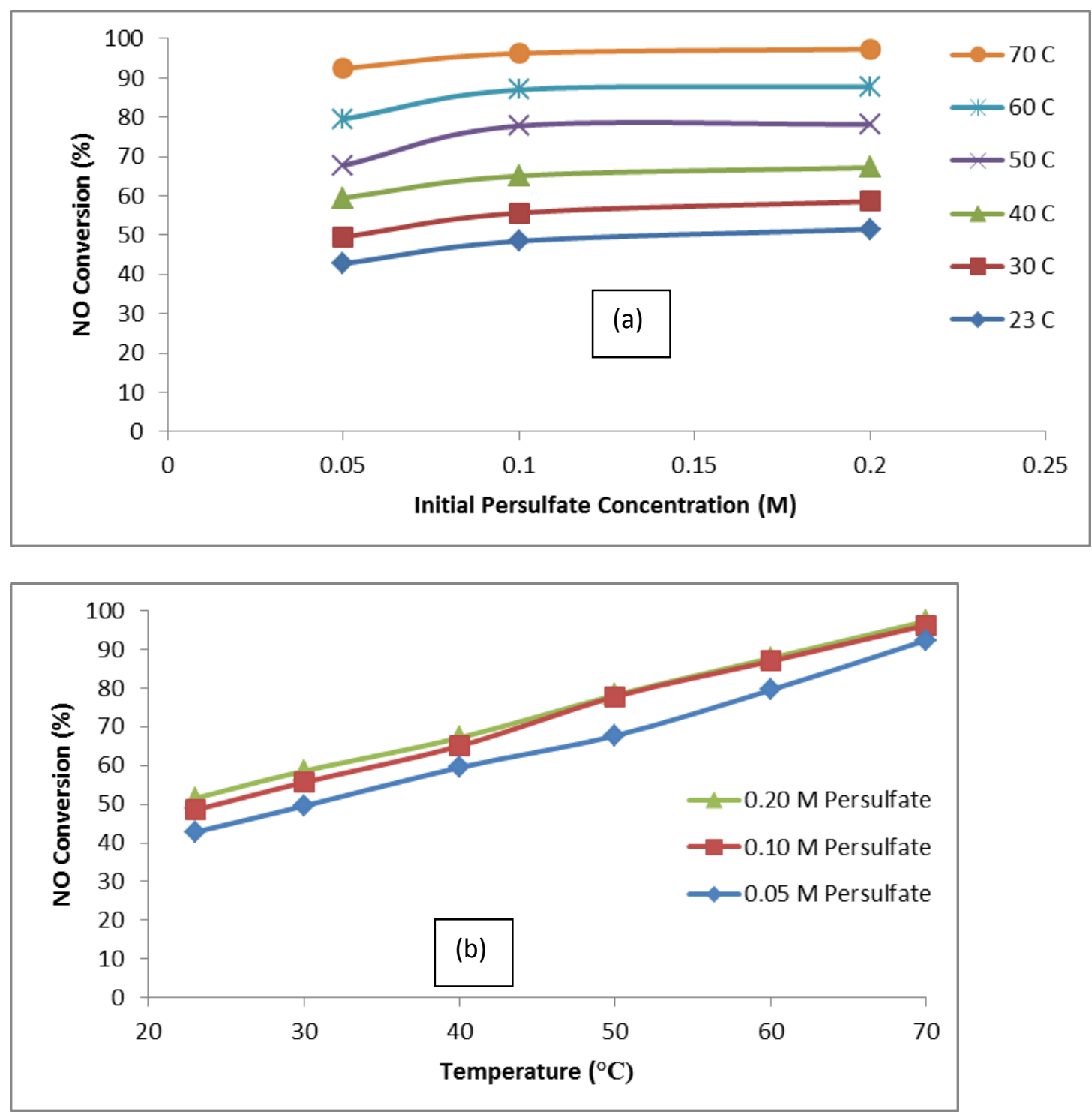

Figure 3. Dependence of $\mathrm{NO}$ fractional conversions on different initial $\mathrm{Na}_{2} \mathrm{~S}_{2} \mathrm{O}_{8}$ concentrations $(0.05,0.10$ and $0.20 \mathrm{M})$ with $0.01 \mathrm{MFe}^{2+}$ and $0.01 \mathrm{M} \mathrm{Na2-EDTA}$ at various temperatures (23-70 $\left.{ }^{\circ} \mathrm{C}\right)$ : $\mathrm{NO}$ conversion as a function of (a) $\mathrm{Na}_{2} \mathrm{~S}_{2} \mathrm{O}_{8}$ concentration and (b) temperature.

It is also obvious from these results that increasing the temperature of the system at the same persulfate level led to an increased conversion of NO. The rate constants of PS decomposition 
have been reported to be $1.0 \times 10^{-7} \mathrm{~s}^{-1}$ and $5.7 \times 10^{-5} \mathrm{~s}^{-1}$ (measured at $\mathrm{pH} 1.3$ ) at $25^{\circ} \mathrm{C}$ and $70{ }^{\circ} \mathrm{C}$, respectively, suggesting that the rate constant at $70{ }^{\circ} \mathrm{C}$ is 570 times greater than that obtained at $25^{\circ} \mathrm{C} .[21]$ The activation energy for the PS thermolysis has been reported to be $33.5 \mathrm{kcal} \mathrm{mol}^{-1}$, indicating that decomposition of PS is much faster at high temperature than at low temperature.[35] This means that the thermal activation simply enhances the rate of generation of reactive radicals at the same PS concentration. Therefore, it is expected that elevated temperature could promote the decomposition of PS to form more sulfate radicals, resulting in an increased removal of NO. As evidence from Table 1, oxidation in PS solution occurs through reactions with the radicals generated by the decomposition of PS (R1-R3). The reaction between $\mathrm{OH}^{*}$ and $\mathrm{NO}(\mathrm{R} 5)$ is about a factor of 100 faster than reaction between $\mathrm{OH}^{*}$ or $\mathrm{SO}_{4}^{--}$with $\mathrm{Fe}^{2+}$ (R11 and $\mathrm{R} 12$ ), and a factor of 10 faster than even its self-recombination reaction (R14). Also, $\mathrm{OH}^{*}$ and $\mathrm{SO}_{4}^{--}$generated are more likely to react directly with $\mathrm{NO}$ as in reactions (R4-R5). It is expected that further addition of PS dose from 0.10 to 0.20 leads to the production of larger amounts of sulfate radicals $\left(\mathrm{SO}_{4}^{--}\right)$, which became more pronounced at the higher temperatures.[20] On the other hand, in a PS-driven process, excess $\mathrm{SO}_{4}^{--}$(from PS overdose) may recombine into $\mathrm{S}_{2} \mathrm{O}_{8}^{2-}$ (R15), and additionally react with the PS anion (R16) or be scavenged by $\mathrm{Fe}^{2+}$ (R12). These reactions may become significant to compete with the $\mathrm{SO}_{4}^{--} / \mathrm{NO}_{\mathrm{x}}$ reactions in solution. Therefore, the slowing down of the NO conversion with increasing PS and temperature (at optimal initial concentrations of both $\mathrm{Fe}^{2+}$ and EDTA, i.e., $\left.0.01 \mathrm{M}\right)[19,25]$ can be attributed to the combined effects of excessive release of $\mathrm{SO}_{4}^{--}$resulting in the enhancement of selfrecombination and inter-combination of radicals $\left(\mathrm{SO}_{4}^{--}\right.$and $\left.\mathrm{OH}^{*}\right)$ as shown in reactions (R13-R17). 
Table 1. Proposed Reaction Scheme for NO Removal by the Combined Persulfate and $\mathrm{Fe}^{2+}$-EDTA Systems

\begin{tabular}{|c|c|c|}
\hline R\# Reaction & Kinetic Constant & Refs. \\
\hline \multicolumn{3}{|c|}{ Persulfate Degradation and NO Consumption by Radicals } \\
\hline$R 1 S_{2} \mathrm{O}_{8}^{2-}+$ heat $\stackrel{k_{1}}{\rightarrow} 2 \mathrm{SO}_{4}^{*-}$ & $\begin{array}{l}1.0 \times 10^{-7}\left(25^{\circ} \mathrm{C}\right) \\
\text { or } 5.7 \times 10^{-5} \mathrm{~s}^{-1}\left(70^{\circ} \mathrm{C}\right)\end{array}$ & 18 \\
\hline $\mathrm{R} 2 \mathrm{~S}_{2} \mathrm{O}_{8}^{2-}+\mathrm{Fe}^{2+} \stackrel{k_{2}}{\rightarrow} \mathrm{SO}_{4}^{2-}+\mathrm{SO}_{4}^{*-}+\mathrm{Fe}^{3+}$ & $1.7-2.7 \times 10^{1} M^{-1} s^{-1}\left(70^{\circ} \mathrm{C}\right)$ & 17 \\
\hline $\mathrm{R3} \mathrm{SO}_{4}^{*-}+\mathrm{H}_{2} \mathrm{O} \stackrel{k_{3}}{\rightarrow} \mathrm{HSO}_{4}^{-}+\mathrm{OH}^{*}$ & $6.6 \times 10^{2} s^{-1}$ & 17 \\
\hline $\mathrm{R} 4 \mathrm{SO}_{4}^{*-}+\mathrm{NO}+\mathrm{H}_{2} \mathrm{O} \stackrel{k_{4}}{\rightarrow} \mathrm{HSO}_{4}^{-}+\mathrm{NO}_{2}^{-}+\mathrm{H}^{+}$ & & 16 \\
\hline $\mathrm{R} 5 \mathrm{OH}^{*}+\mathrm{NO}^{k_{5}} \rightarrow \mathrm{H}^{+}+\mathrm{NO}_{2}^{-}$ & $2 \times 10^{10} M^{-1} s^{-1}$ & 17 \\
\hline $\mathrm{R} 6 \mathrm{OH}^{*}+\mathrm{NO}_{2}^{-} \stackrel{k_{6}}{\rightarrow} \mathrm{OH}^{-}+\mathrm{NO}_{2}$ & $1 \times 10^{10} M^{-1} s^{-1}$ & 38 \\
\hline R7 $\mathrm{S}_{2} \mathrm{O}_{8}^{2-}+\mathrm{NO}_{2}^{-} \stackrel{k_{7}}{\rightarrow} \mathrm{SO}_{4}^{2-}+\mathrm{SO}_{4}^{*-}+\mathrm{NO}_{2}$ & & 28 \\
\hline $\mathrm{R} \mathrm{NO}_{2}^{-}+\mathrm{SO}_{4}^{*-} \stackrel{k_{3}}{\longrightarrow} \mathrm{SO}_{4}^{2-}+\mathrm{NO}_{2}$ & $9.8 \times 10^{8} M^{-1} S^{-1}$ & 38 \\
\hline $\mathrm{R} \mathrm{NO}_{2}+\mathrm{OH}^{*} \stackrel{k_{9}}{\rightarrow} \mathrm{H}^{+}+\mathrm{NO}_{3}^{-}$ & $4.5 \times 10^{9} M^{-1} S^{-1}$ & 38 \\
\hline \multicolumn{3}{|l|}{ Direct Consumption of NO by Persulfate } \\
\hline $\mathrm{R} 10 \mathrm{~S}_{2} \mathrm{O}_{8}^{2-}+\mathrm{NO}+\mathrm{H}_{2} \mathrm{O} \stackrel{k_{10}}{\longrightarrow} 2 \mathrm{HSO}_{4}^{-}+\mathrm{NO}_{2}$ & $\begin{array}{l}2.59 \times 10^{-4} M^{-1} s^{-1}\left(23^{\circ} \mathrm{C}\right) \\
1.5 \times 10^{-3} M^{-1} s^{-1}\left(90^{\circ} \mathrm{C}\right)\end{array}$ & 17 \\
\hline \multicolumn{3}{|l|}{ Reactions of Ferrous Ion with Radicals } \\
\hline$R 11 \mathrm{Fe}^{2+}+\mathrm{OH}^{\cdot} \stackrel{k_{11}}{\rightarrow} \mathrm{Fe}^{3+}+\mathrm{OH}^{-}$ & $3.2 \times 10^{8} M^{-1} s^{-1}$ & 28 \\
\hline $\mathrm{R}_{12} \mathrm{SO}_{4}^{*-}+\mathrm{Fe}^{2+} \stackrel{k_{12}}{\longrightarrow} \mathrm{Fe}^{3+}+\mathrm{SO}_{4}^{2-}$ & $4.6 \times 10^{9}, 3.0 \times 10^{8} M^{-1} S^{-1}$ & 28 \\
\hline \multicolumn{3}{|l|}{ Radical inter/re-combination \& persulfate Interaction } \\
\hline $\mathrm{R} 13 \mathrm{SO}_{4}^{*-}+\mathrm{OH}^{\cdot} \stackrel{k_{13}}{\longrightarrow} \mathrm{HSO}_{4}^{-}+0.5 \mathrm{O}_{2}$ & $1 \times 10^{10} M^{-1} s^{-1}$ & 28 \\
\hline$R 14 \mathrm{OH}^{*}+\mathrm{OH}^{*} \stackrel{k_{14}}{\longrightarrow} \mathrm{H}_{2} \mathrm{O}_{2}$ & $5.5 \times 10^{10} \mathrm{M}^{-1} \mathrm{~s}^{-1}$ & 38 \\
\hline
\end{tabular}




\begin{tabular}{|c|c|c|}
\hline $\mathrm{R}_{15} \mathrm{SO}_{4}^{*-}+\mathrm{SO}_{4}^{*-} \stackrel{k_{15}}{\longrightarrow} \mathrm{S}_{2} \mathrm{O}_{8}^{2-}$ & $4.0 \times 10^{8} M^{-1} S^{-1}$ & 16 \\
\hline $\mathrm{R}_{16} \mathrm{SO}_{4}^{*-}+\mathrm{S}_{2} \mathrm{O}_{8}^{2-} \stackrel{k_{16}}{\longrightarrow} \mathrm{S}_{2} \mathrm{O}_{8}^{*-}+\mathrm{SO}_{4}^{2-}$ & $6.1 \times 10^{5} M^{-1} S^{-1}$ & 16 \\
\hline $\mathrm{R} 17 \mathrm{OH}^{*}+\mathrm{S}_{2} \mathrm{O}_{8}^{2-} \stackrel{k_{17}}{\longrightarrow} \mathrm{S}_{2} \mathrm{O}_{8}^{*-}+\mathrm{OH}^{-}$ & $1.2 \times 10^{7} M^{-1} s^{-1}$ & 17 \\
\hline \multicolumn{3}{|l|}{ NO Absorption Reaction by $\mathrm{FeSO}_{4}$} \\
\hline $\mathrm{R} 18 \mathrm{FeSO}_{4}+\mathrm{NO} \stackrel{\mathrm{K}_{19}}{\Leftrightarrow} \mathrm{Fe}(\mathrm{NO}) \mathrm{SO}_{4}$ & & 25 \\
\hline \multicolumn{3}{|l|}{ Reactions of $\mathrm{Fe}^{2+}$-EDTA with $\mathrm{NO}_{\mathrm{x}}$} \\
\hline$R 19 \mathrm{Fe}^{2+}+\mathrm{EDTA}^{2-} \stackrel{\mathrm{K}_{19}}{\Leftrightarrow} \mathrm{Fe}^{2+}-E D T A$ & & 27,31 \\
\hline$R 20 \mathrm{Fe}^{2+}-E D T A+\mathrm{NO} \stackrel{\mathrm{K}_{20}}{\Leftrightarrow} \mathrm{Fe}^{2+}-E D T A(\mathrm{NO})$ & $\begin{array}{l}3.6 \times 10^{6} M^{-1}\left(25^{\circ} \mathrm{C}\right), \\
6.0 \times 10^{5} M^{-1}\left(50^{\circ} \mathrm{C}\right)\end{array}$ & 27,31 \\
\hline $\begin{array}{l}\mathrm{R} 212 \mathrm{Fe}^{2+}-\mathrm{EDTA}+\mathrm{NO}_{2}^{-}+2 \mathrm{H}^{+} \\
\stackrel{\mathrm{K}_{21}}{\Leftrightarrow} \mathrm{Fe}^{2+}-\mathrm{EDTA}(\mathrm{NO})+\mathrm{Fe}^{3+}-\mathrm{EDTA}+\mathrm{H}_{2} \mathrm{O}\end{array}$ & & 31 \\
\hline $\begin{array}{l}\text { R22 } 2 \mathrm{Fe}^{2+}-\mathrm{EDTA}(\mathrm{NO})+2 \mathrm{Fe}^{2+}-\mathrm{EDTA}+4 \mathrm{H}^{+} \\
\stackrel{k_{22}}{\longrightarrow} 4 \mathrm{Fe}^{3+}-\mathrm{EDTA}+\mathrm{N}_{2}+2 \mathrm{H}_{2} \mathrm{O}\end{array}$ & & 31 \\
\hline $\mathrm{R}_{23} 2 \mathrm{Fe}^{2+}-\mathrm{EDTA}+2 \mathrm{NO}_{2} \stackrel{\mathrm{K}_{22}}{\Leftrightarrow} \mathrm{Fe}^{2+}-\mathrm{EDTA}(\mathrm{NO})+\mathrm{Fe}^{3+}-\mathrm{EDTA}+\mathrm{N}$ & & 31 \\
\hline \multicolumn{3}{|l|}{ Radical Reactions Under Alkaline Condition } \\
\hline $\mathrm{R} 24 \mathrm{SO}_{4}^{*-}+\mathrm{OH}^{-} \stackrel{k_{24}}{\longrightarrow} \mathrm{SO}_{4}^{2-}+\mathrm{OH}^{*}$ & $1.4 \times 10^{7} M^{-1} s^{-1}$ & 14 \\
\hline $\mathrm{R} 25 \mathrm{OH}^{*}+\mathrm{OH}^{-} \stackrel{\mathrm{K}_{25}}{\Leftrightarrow} \mathrm{O}^{*-}+\mathrm{H}_{2} \mathrm{O}$ (at very high $\left.\mathrm{pH}\right)$ & & 14 \\
\hline \multicolumn{3}{|l|}{ Reactions Under Acidic Condition } \\
\hline $\mathrm{R} 26 \mathrm{~S}_{2} \mathrm{O}_{8}^{2-}+\mathrm{H}^{+} \stackrel{k_{26}}{\rightarrow} \mathrm{HS}_{2} \mathrm{O}_{8}^{-}$ & & 18,30 \\
\hline $\mathrm{R} 27 \mathrm{HS}_{2} \mathrm{O}_{8}^{-} \stackrel{k_{27}}{\longrightarrow} \mathrm{H}^{+}+2 \mathrm{SO}_{4}^{*-}$ & & 18,30 \\
\hline $\mathrm{R} 28 \mathrm{~S}_{2} \mathrm{O}_{8}^{2-}+\mathrm{H}_{2} \mathrm{O} \stackrel{\mathrm{H}^{+}, k_{29}}{\longrightarrow} \mathrm{H}_{2} \mathrm{SO}_{5}+\mathrm{SO}_{4}^{2-}(\mathrm{pH}<3)$ & & 18,30 \\
\hline Reduction of $\mathrm{Fe}^{3+}$-EDTA and $\mathrm{Fe}^{2+}$-EDTA(NO) & & \\
\hline
\end{tabular}




\begin{tabular}{|c|c|c|}
\hline$R 29 \mathrm{Fe}^{3+}-\mathrm{EDTA}+\mathrm{NO}_{2}^{-} \stackrel{k_{29}}{\longrightarrow} \mathrm{Fe}^{2+}-\mathrm{EDTA}+\mathrm{NO}_{2}$ & & 28 \\
\hline $\mathrm{R3} \mathrm{Fe}^{3+}-\mathrm{EDTA}+\mathrm{HSO}_{4}^{-} \stackrel{k_{30}}{\longrightarrow} \mathrm{Fe}^{2+}-E D T A+0.5 S_{2} \mathrm{O}_{8}^{2-}+\mathrm{H}^{+}$ & & 28 \\
\hline$R 31 \mathrm{Fe}^{3+}-E D T A+\mathrm{SO}_{4}^{+-} \stackrel{k_{31}}{\longrightarrow} \mathrm{Fe}^{2+}-E D T A+0.5 S_{2} \mathrm{O}_{8}^{2-}$ & & 28 \\
\hline $\begin{array}{l}\mathrm{R}^{2} \mathrm{Fe}^{2+}-\mathrm{EDTA}(\mathrm{NO})+2 \mathrm{HSO}_{4}^{-} \stackrel{k_{32}}{\longrightarrow} \mathrm{Fe}^{2+}-\mathrm{EDTA} \\
+\mathrm{SO}_{4}^{2-}+\mathrm{H}_{2} \mathrm{SO}_{5}+0.5 \mathrm{~N}_{2}\end{array}$ & & 28 \\
\hline$R 33 \mathrm{Fe}^{2+}-\mathrm{EDTA}(\mathrm{NO})+\mathrm{SO}_{4}^{2-} \stackrel{\mathrm{K}_{33}}{\Leftrightarrow} \mathrm{Fe}^{2+}-\mathrm{EDTA}(\mathrm{NO}) \mathrm{SO}_{4}^{2-}$ & & 28 \\
\hline $\begin{array}{l}R 343 \mathrm{Fe}^{2+}-\mathrm{EDTA}(\mathrm{NO})+4 \mathrm{HSO}_{4}^{-} \stackrel{\mathrm{K}_{24}}{\Leftrightarrow} 3 \mathrm{Fe}^{2+}-\mathrm{EDTA} \\
+2 \mathrm{HON}\left(\mathrm{SO}_{4}\right)_{2}^{2-}+0.5 \mathrm{~N}_{2}+\mathrm{H}_{2} \mathrm{O}\end{array}$ & & 34,45 \\
\hline $\begin{array}{l}R 354 \mathrm{Fe}^{2+}-\mathrm{EDTA}(\mathrm{NO})+4 \mathrm{HSO}_{4}^{-} \stackrel{k_{35}}{\longrightarrow} 4 \mathrm{Fe}^{2+}-\mathrm{EDTA} \\
+2 \mathrm{HON}\left(\mathrm{SO}_{4}\right)_{2}^{2-}+\mathrm{H}_{2} \mathrm{~N}_{2} \mathrm{O}_{2}\end{array}$ & & 34,45 \\
\hline$R 36 \mathrm{H}_{2} \mathrm{~N}_{2} \mathrm{O}_{2} \stackrel{k_{36}}{\longrightarrow} \mathrm{N}_{2} \mathrm{O}+\mathrm{H}_{2} \mathrm{O}$ & & 34,35 \\
\hline $\begin{array}{l}\mathrm{R37} 2 \mathrm{Fe}^{2+}-\mathrm{EDTA}(\mathrm{NO})+\mathrm{SO}_{4}^{--} \stackrel{\mathrm{K}_{37}}{\Leftrightarrow} 2 \mathrm{Fe}^{2+}-\mathrm{EDTA} \\
+(\mathrm{NO})_{2} \mathrm{SO}_{4}^{2-}\end{array}$ & & 34,45 \\
\hline$R 38(\mathrm{NO})_{2} \mathrm{SO}_{4} \stackrel{2-\stackrel{\mathrm{K}_{3}}{\Leftrightarrow}}{\Leftrightarrow} \mathrm{N}_{2} \mathrm{O}+\mathrm{SO}_{4}^{2-}+0.5 \mathrm{O}_{2}$ & & 34,45 \\
\hline$R 393 \mathrm{~N}_{2} \mathrm{O}+\mathrm{H}_{2} \mathrm{O} \stackrel{k_{39}}{\longrightarrow} 2 \mathrm{HNO}_{2}+2 \mathrm{~N}_{2}\left(\mathrm{O}_{2}\right.$ deficient solution $)$ & & 28,46 \\
\hline$R 40 \mathrm{Fe}^{2+}-\mathrm{EDTA}(\mathrm{NO})+\mathrm{SO}_{4}^{--} \stackrel{\mathrm{K}_{40}}{\Leftrightarrow} \mathrm{Fe}^{2+}{ }_{-} \mathrm{EDTA}(\mathrm{NO}) \mathrm{SO}_{4}^{2-}$ & & 28 \\
\hline \multicolumn{3}{|l|}{ OH-Radical Induced Degradation of EDTA } \\
\hline $\mathrm{R} 41[\mathrm{Fe}(\text { edta })]^{2-}+\mathrm{OH}^{*} \stackrel{k_{41}}{\longrightarrow} \quad[\mathrm{Fe}(\text { edta })]^{-}+\mathrm{OH}^{-}$ & $0.4-5.0 \times 10^{9} M^{-1} s^{-1}$ & 36,37 \\
\hline $\mathrm{R} 42[\mathrm{Fe}(\text { edta })]^{-}+\mathrm{OH}^{*} \stackrel{k_{42}}{\longrightarrow} \quad \mathrm{H}_{2} \mathrm{O} \quad+$ products & $0.52-2.0 \times 10^{9} M^{-1} s^{-1}$ & 36,37 \\
\hline \multicolumn{3}{|l|}{ Iron-EDTA pH-dependent Equilibrium and Speciation } \\
\hline $\mathrm{R} 43 \mathrm{Fe}^{2+}+\mathrm{EDTA}^{4-}+\mathrm{H}^{+} \stackrel{p H=1, \log _{43}=2,8}{\Longleftrightarrow}$ FeHEDTA $^{-}$ & & 40 \\
\hline $\mathrm{R} 44 \mathrm{Fe}^{2+}+\mathrm{EDTA}^{4-} \stackrel{p H=6, \operatorname{Logk}_{44}=14.25}{\Longleftrightarrow} \mathrm{FeEDTA}^{2-}$ & & 40 \\
\hline
\end{tabular}




\begin{tabular}{|c|c|}
\hline $\mathrm{R} 45 \mathrm{FeEDTA}^{2-}+\mathrm{OH}^{-} \stackrel{p H=9, \log _{\mathrm{K}}=4,87}{\Longleftrightarrow}$ FeEDTA $(\mathrm{OH})^{3-}$ & 40 \\
\hline $\mathrm{R} 46 \mathrm{FeEDTA}(\mathrm{OH})^{3-}+\mathrm{OH}^{-} \stackrel{p H=10.5, \log _{46}=4,1}{\Longleftrightarrow}$ FeEDTA $(\mathrm{OH})^{4-}$ & 40 \\
\hline $\begin{array}{l}\mathrm{R} 47 \\
\text { FeEDTA }(\mathrm{OH})^{4-}+\mathrm{OH}^{-} \stackrel{p H=10.5, \log _{47}=4,1}{\Longleftrightarrow} \mathrm{Fe}(\mathrm{OH})_{2} \downarrow+E D T A^{4-}\end{array}$ & 40 \\
\hline \multicolumn{2}{|l|}{ Reduction of Ferric Chelates by Bisulfite } \\
\hline $\mathrm{R} 48 \mathrm{Fe}^{3+}-\mathrm{EDTA}+\mathrm{HSO}_{3}^{-} \stackrel{k_{40}}{\longrightarrow} \mathrm{FeSO}_{3}^{+}+H^{+}+\mathrm{EDTA}$ & 34 \\
\hline $\mathrm{R} 49 \mathrm{FeSO}_{3}^{+} \stackrel{k_{49}}{\longrightarrow} \mathrm{Fe}^{2+}+\mathrm{SO}_{3}^{*-}$ & 34 \\
\hline $\mathrm{R} 50 \mathrm{SO}_{3}^{*-}+\mathrm{OH}^{*} \stackrel{k_{50}}{\longrightarrow} \mathrm{HSO}_{4}^{-}$ & 34 \\
\hline
\end{tabular}

\subsection{Effect of EDTA Concentrations and Temperature on NO Removal.}

Figure 4 illustrates the effects of different EDTA concentrations $(0.005,0.01,0.02$ and $0.05 \mathrm{M})$ with $0.1 \mathrm{MPS}$ and $0.01 \mathrm{Fe}^{2+}$ on $\mathrm{NO}$ concentration profiles at temperature range $23-70{ }^{\circ} \mathrm{C}$. At $23{ }^{0} \mathrm{C}$ the steady-state $\mathrm{NO}$ conversion increases significantly $(38.0 \%$ to $48.5 \%)$ as EDTA concentration increases from 0.005 to $0.01 \mathrm{M}$, with the marginal conversion increase getting smaller at $0.02 \mathrm{M}(52.6 \%)$ but with decreasing to $51.3 \%$ as EDTA concentration further increased to $0.05 \mathrm{M}$. The trend of the results at $30{ }^{\circ} \mathrm{C}$ is similar to that of $23{ }^{\circ} \mathrm{C}$, showing $\mathrm{NO}$ conversion of $48.7 \%, 55.6 \%, 61.8 \%$ and $61.2 \%$ with increasing EDTA concentrations. However, at higher temperatures, the antagonistic effect of increasing EDTA concentrations becomes more pronounced. At $40{ }^{\circ} \mathrm{C}$, NO conversions are $60.7 \%, 65.1 \%$ and 66.2 with EDTA concentrations of 0.005, 0.01, and 0.02 M, respectively, but at 0.05 M EDTA the solution losses almost all its absorption capacity and NO profile showing a breakthrough and a steady-state conversion of only $19.1 \%$ as shown in Figure 4(c). This behavior was also observed at 50, 60 and $70{ }^{\circ} \mathrm{C}$ as shown in Figure $4\left(\mathrm{~d}\right.$, e and f). For example, at $50{ }^{\circ} \mathrm{C}$, NO removal increases from $70.7 \%$ to 
$77.8 \%$ when EDTA concentration is increased from 0.005 to $0.01 \mathrm{M}$, while at $0.02 \mathrm{M}$ it actually decreased to $73.6 \%$.
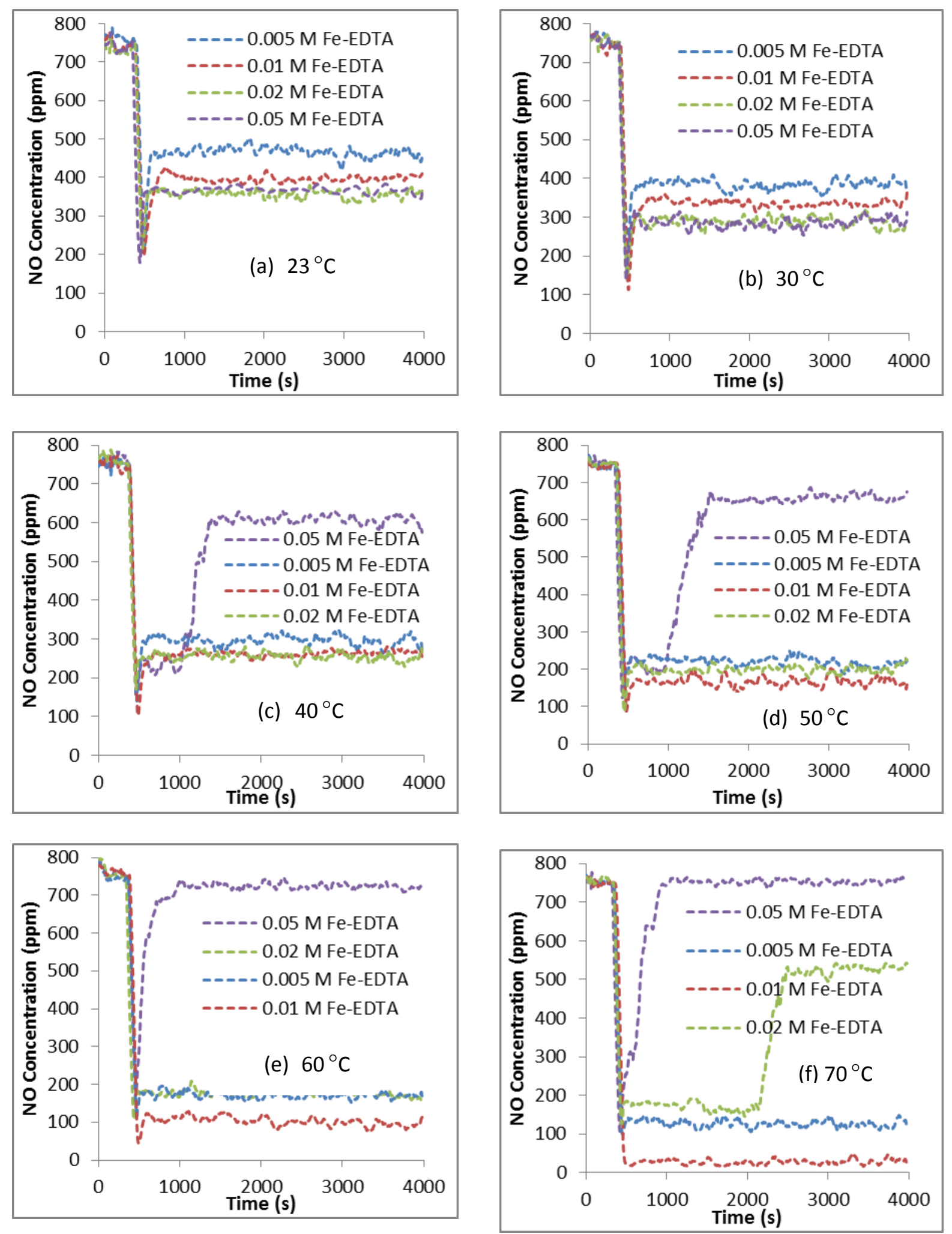
Figure 4. NO concentration profiles for different initial Na2-EDTA concentrations $(0.005,0.01$, 0.02 and $0.05 \mathrm{M}$ ) for $0.1 \mathrm{M} \mathrm{Na}_{2} \mathrm{~S}_{2} \mathrm{O}_{8}$ and $0.01 \mathrm{MFe}^{2+}$ solution system at various temperatures (23-70 ${ }^{\circ} \mathrm{C}$ ): (a) 23, (b) 30, (c) 40, (d) 50, (e) 60 and (f) $70{ }^{\circ} \mathrm{C}$.

But at 0.05 M EDTA the solution losses almost all its absorption capacity and NO profile could be seen to rise upward sharply after maintaining absorption for a short time, resulting in an eventual NO removal of only $13.3 \%$. Also, at $70^{\circ} \mathrm{C}$, NO conversion increased from 83.4 to 96.3 $\%$ as EDTA concentration increased from 0.005 to $0.01 \mathrm{M}$ EDTA. However, it should be noted that, at 0.02 M EDTA the initial NO removal appears to be $78.0 \%$, but the solution losses its absorption capacity significantly in about $2200 \mathrm{~s}$, resulting in a sudden rise in NO profile before stabilizing at 29.2\%. In Figure 5, the NO conversion is plotted as a function of temperature for the different EDTA concentrations. With $0.10 \mathrm{M} \mathrm{Na}_{2} \mathrm{~S}_{2} \mathrm{O}_{8}, 0.01 \mathrm{Fe}^{2+}$ and $\leq 0.01 \mathrm{M}$ EDTA, NO conversion increased with temperature from 23 to $70{ }^{\circ} \mathrm{C}$ (with the rate highest for $0.01 \mathrm{M}$ EDTA), and showed significant improvement over the case with no EDTA over the entire temperature range. Interestingly, it can be observed that with 0.01 EDTA, the increase in NO conversion with temperature is steep and linear over the whole temperature range. However, with $0.02 \mathrm{M}$ EDTA, the NO conversion increases almost linearly up to $60{ }^{\circ} \mathrm{C}(76.0 \%)$ before dropping sharply at $70{ }^{\circ} \mathrm{C}$ with NO conversion of $29.2 \%$ (which is below the value observed in the absence of EDTA of about 69\%; , and with 0.05 M EDTA, the rapid decline of NO conversion started even earlier at $30{ }^{\circ} \mathrm{C}$.

In addition to the $\mathrm{Fe}^{2+}$ activation of PS in reaction (R2), $\mathrm{Fe}^{2+}$ and EDTA react with one another according to the reversible reaction (R19). This reaction dictates the presence of $\mathrm{Fe}^{2+}$, EDTA and $\mathrm{Fe}^{2+}$-EDTA in the solution, with enough $\mathrm{Fe}^{2+}$ expected to remain in the solution for PS activation. The kinetics of this reversible reaction fixes the amount of $\mathrm{Fe}^{2+}$-EDTA produced 
in the solution. The $\mathrm{Fe}^{2+}$-EDTA absorbs $\mathrm{NO}$ by a reversible binding producing nitrosyl compound as represented in reaction (R20). It is observed from both Figure 4 and Figure 5 that the effectiveness of the NO removal is dependent on both temperature and EDTA concentration. The results suggest that at higher EDTA doses, EDTA depletes $\mathrm{Fe}^{2+}$ to the point of significantly lowering the amount of $\mathrm{Fe}^{2+}$ available for PS activation. As noted at $40{ }^{\circ} \mathrm{C}$ and $50{ }^{\circ} \mathrm{C}$ (Figure $4 \mathrm{c}$ and 4d), the initial results for $0.05 \mathrm{M}$ EDTA were not as stable, suggesting that higher PS activation predominates initially resulting in higher NO removal but absorption efficiencies are shortly lost as $\mathrm{Fe}^{2+}$ is depleted with time. As the temperature increases (Figure 4e and 4f) the loss of NO absorption efficiency appears to be immediate.

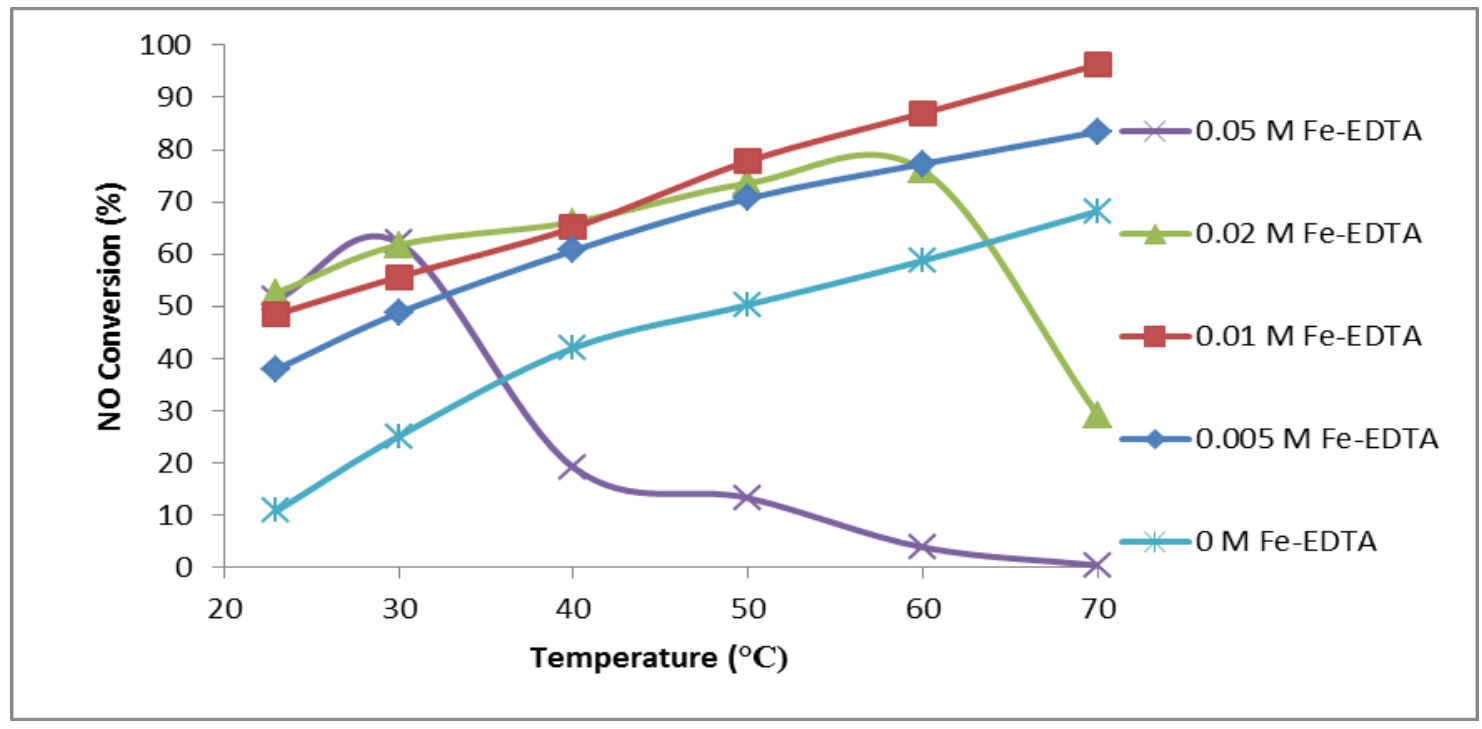

Figure 5. Dependence of $\mathrm{NO}$ fractional conversions on temperature $\left(23-70{ }^{\circ} \mathrm{C}\right)$ for $0.1 \mathrm{M}$ $\mathrm{Na}_{2} \mathrm{~S}_{2} \mathrm{O}_{8}$ and $0.01 \mathrm{MFe}^{2+}$ solution system in the presence of different initial concentrations of $N a_{2}-E D T A$.

It should be noted that high temperature reduces the physical solubility of NO, which is unfavorable for gas-liquid mass transfer. On the other hand, the mass transfer coefficient $\left(\mathrm{K}_{\mathrm{La}}\right)$ increases with temperature due to the acceleration of molecular diffusion, and the driving force 
provided by chemical reaction in a reactive gas-liquid process. In a recent study, Adewuyi et al (2014) determined chemical reaction plays the dominant role in the temperature range of this study.[20] Therefore, these results could be partly attributed to the reversible binding of NO with $\mathrm{Fe}^{2+}$-EDTA in reaction (20).[25, 36] The forward reaction constant, $\mathrm{k}_{18}$ (in R18) is higher in the lower temperature $\left(6 \times 10^{7} \mathrm{M}^{-1} \mathrm{~s}^{-1}\right.$ at $\left.25^{\circ} \mathrm{C}\right)$ compared to the value at the higher temperature $(3.7$ $\times 10^{7} \mathrm{M}^{-1} \mathrm{~s}^{-1}$ at $50{ }^{\circ} \mathrm{C}$ ). At $50{ }^{\circ} \mathrm{C}$, the backward reaction constant, $\mathrm{k}-20$ (in R20) increases from 6 to $60 \mathrm{~s}^{-1}$, resulting in a lower value of equilibrium constant $\mathrm{K}_{20}$ at the higher temperature. However, the $\mathrm{Fe}^{2+}$-EDTA reversible binding with $\mathrm{NO}$ (R20) is slower at higher temperature as backward reaction rate increases. It should be noted that the use of $\mathrm{Fe}^{2+}$-EDTA has advantage over $\mathrm{Fe}^{2+}$-only activated PS as iron chelating prevents or minimizes the scavenging of $\mathrm{OH}^{*}$, and hence, prevents suppression of Fenton or Fenton-like reactions. Thus, in reactions (R11-R12), where $\mathrm{Fe}^{2+}$ was responsible for the scavenging of $\mathrm{OH}^{*}$ and $\mathrm{SO}_{4}^{--}$, such reactions are suppressed when $\mathrm{Fe}^{2+}$-EDTA is used instead of $\mathrm{Fe}^{2+}$ only. It has also been reported that $\mathrm{NO}$ binds to $\mathrm{FeSO}_{4}$ in solution in a relatively very slow reaction (R18) with the order of magnitude of the reaction constant four times less than that of reaction (R20), and hence, considered insignificant in the removal of $\mathrm{NO}$ by the $\mathrm{Fe}^{2+}$-EDTA absorption system.[29] However, it may play a significant role in combined PS and $\mathrm{Fe}^{2+}$-EDTA systems. In $\mathrm{Fe}^{2+}$-activated PS system, all the $\mathrm{Fe}^{2+}$ reacts very quickly and remains virtually non-existent in the solution and the possibility of reaction (R18) is negligible to nil. But in the combined PS and $\mathrm{Fe}^{2+}$-EDTA systems, the concentration of $\mathrm{Fe}^{2+}$ is determined by the equilibrium reaction (R20), and the possibility of reaction (R18) is reinvigorated and could aid the removal efficiency of NO. $\mathrm{Fe}^{2+}$-EDTA also reacts with $\mathrm{NO}_{2}^{-}$and $\mathrm{NO}_{2}$ by reactions (R21) and R23), and acts as an electron donor in the denitrification of $\mathrm{Fe}^{2+}$ EDTA(NO) in a chemical reaction (R22) much as in biological processes where ethanol is 
known to act as a electron donor compound.[36] As previously observed, the production of both $\mathrm{Fe}^{2+}$-EDTA(NO) and $\mathrm{Fe}^{3+}$-EDTA could reduce the absorption capability of the solution with time. The success of an effective NO removal by $\mathrm{Fe}^{2+}$-EDTA was attributed to the efficient reduction of $\mathrm{Fe}^{2+}$-EDTA(NO) and $\mathrm{Fe}^{3+}$-EDTA, and regeneration of $\mathrm{Fe}^{2+}$-EDTA into the system. Sulfate and other PS derived ions in the system are also thought to effectively accomplish this task. It has been reported that $\mathrm{HSO}_{3}^{-}$and/or $\mathrm{SO}_{3}^{2-}$ can be used to reduce $\mathrm{Fe}^{2+}$-EDTA(NO) and $\mathrm{Fe}^{3+}$-EDTA.[37]

In a neutral medium $\mathrm{NO}_{2}{ }^{-}$could react with $\mathrm{Fe}^{3+}$-EDTA, serving as an electron donor to reduce it to $\mathrm{Fe}^{2+}$-EDTA as in reaction (R29), and thus aiding iron recycling to maintain PS activation.[38] In addition, reactions (R30-R40) involving sulfate anions and radicals have been proposed as pathways for the reduction of $\mathrm{Fe}^{2+}-\mathrm{EDTA}(\mathrm{NO})$ and $\mathrm{Fe}^{3+}$-EDTA back to $\mathrm{Fe}^{2+}-$ EDTA.[25, 39] Therefore, it could be implied that the PS system also helps $\mathrm{Fe}^{2+}$-EDTA chemistry, producing a complete synergistic and simultaneous relationship. The possible formation of Caro's acid $\left(\mathrm{H}_{2} \mathrm{SO}_{5}\right)$ with regeneration of $\mathrm{Fe}^{2+}$-EDTA in reaction (R32) is noteworthy, since the PMS anion $\left(\mathrm{HSO}_{5}^{-}\right.$) is a known powerful oxidant for both $\mathrm{NO}_{\mathrm{x}}$ and $\mathrm{S}(\mathrm{IV})$ in the $\mathrm{pH}$ range of 6.5-8.5.[10, 40]

The longtime viability of the absorbent solution was also tested at $30{ }^{\circ} \mathrm{C}$ for both $\mathrm{Fe}^{2+}$-PS and the combined PS and $\mathrm{Fe}^{2+}$-EDTA processes. For the prolonged period of time $(6 \mathrm{~h}), \mathrm{NO}$ conversion was found to be $28.07 \%$ for $\mathrm{Fe}^{2+}$ activated PS system and $56.88 \%$ for the combined PS and $\mathrm{Fe}^{2+}$-EDTA system as shown in Figure 6. The longtime viability of the combined solution to better sustain NO absorption-oxidation capability suggests the possibility of continuous reduction of both $\mathrm{Fe}^{3+}$-EDTA and $\mathrm{Fe}^{2+}$-EDTA(NO) to $\mathrm{Fe}^{2+}$-EDTA, confirming the beneficial action of PS and its derived radicals and ions on $\mathrm{Fe}^{2+}$-EDTA rejuvenation.[25] 


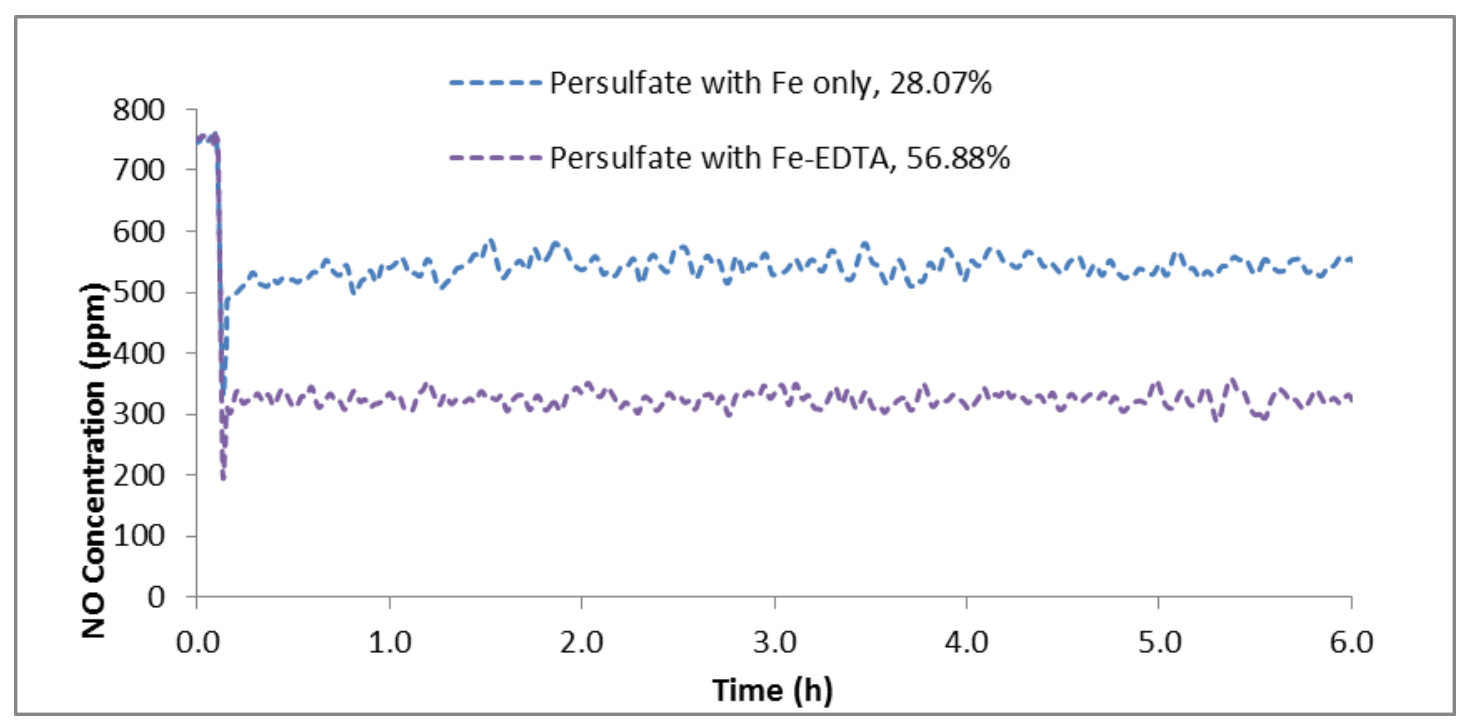

Figure 6. Comparative NO concentration profiles for a prolonged period of time $(6.0 \mathrm{~h})$ for 0.1 $\mathrm{M} \mathrm{Na}_{2} \mathrm{~S}_{2} \mathrm{O}_{8}$ and $0.01 \mathrm{MFe}^{2+}$ solution system in the absence and presence of $0.01 \mathrm{M} \mathrm{Na}-\mathrm{EDTA}$ at $30^{\circ} \mathrm{C}$.

However, as indicated earlier, higher temperatures accelerate rate of activation and can result in very aggressive oxidizing conditions. At higher temperatures and in the presence of optimal amount of $\mathrm{Fe}^{2+}$-EDTA, the decomposition of PS is faster and so is the rate of generation of oxidative species. Also, it is well known that $\mathrm{OH}^{*}$ reacts with Fe-EDTA as in reactions (R41$\mathrm{R} 42$ ), with rate constants (at about $\mathrm{pH}$ 6) ranging from $4.0 \times 10^{8}$ to $5.0 \times 10^{9} \mathrm{M}^{-1} \mathrm{~s}^{-1}$.[41-43] Also, as previously noted, the $\mathrm{OH}^{*}$ and $\mathrm{SO}_{4}^{--}$generated in the reacting system more likely to react with $\mathrm{NO}_{\mathrm{x}}$ species since these reactions are 10 -100 times higher than reactions (R41 and R42) at the optimal EDTA concentrations and lower temperatures. But at higher EDTA concentrations and temperatures, the OH-induced degradation of EDTA could be significant. It has been reported that reaction (R41) has a large activation energy due to the large reorganization energy required.[41] Therefore, the decrease in NO removal with increase in EDTA may also be due to the effect of excessive chelating agents, which may inhibit the reaction of $\mathrm{NO}_{\mathrm{x}}$ species by rapidly 
scavenging $\mathrm{OH}^{*}$. The combinative effects of these reactions could explain why at lower EDTA concentration, PS and $\mathrm{Fe}^{2+}$-EDTA act synergistically to significantly improve NO removal, but antagonistically at the higher EDTA concentration and higher temperature to completely depletes the absorption capacity of the solution for NO as observed in Figures 4 and 5. In general, the degradation of chelating agent by $\mathrm{OH}^{\bullet}$ depends on various factors such as $\mathrm{pH}$, oxidant's dose, concentration of target pollutants, and radical scavengers (e.g., bicarbonate ions).[44]

\subsection{Effect of pH and Temperature on NO Removal:}

The combined effects of $\mathrm{pH}$ and temperature on the NO conversion are illustrated in Figure 7 for $\mathrm{Na}_{2} \mathrm{~S}_{2} \mathrm{O}_{8}(0.1 \mathrm{M})$ and $\mathrm{Fe}^{2+}$-EDTA $(0.01 \mathrm{M})$ reaction system. Figure 7 (a and b) show the NO concentration profiles at 40 and $50{ }^{\circ} \mathrm{C}$. In general, NO removal is lower for both temperatures at very low and high $\mathrm{pH}$ levels compared to mid-pHs. As shown in Figure (7c), the steady state NO conversion (at time $\geq 3000$ s) increases with $\mathrm{pH} 2$ up to $\mathrm{pH} 6.5$ with the marginal increase steeper at $50^{\circ} \mathrm{C}$ compared to $40^{\circ} \mathrm{C}$, but begin to drop for both temperatures beyond $\mathrm{pH} 6.5$. However, from $\mathrm{pH} 6.5$ to $\mathrm{pH} 12$, the drop is more pronounced at $50^{\circ} \mathrm{C}$ than at $\mathrm{pH}$ $40^{\circ} \mathrm{C}$, and by $\mathrm{pH} 12$, the $\mathrm{NO}$ conversion is actually higher at $40^{\circ} \mathrm{C}$ than at $50^{\circ} \mathrm{C}$. Compared with our previous studies with $\mathrm{Na}_{2} \mathrm{~S}_{2} \mathrm{O}_{8}-$ only and $\mathrm{Na}_{2} \mathrm{~S}_{2} \mathrm{O}_{8}-\mathrm{Fe}^{2+}$ systems without EDTA) [17, 19], these results indicate significant improvement in $\mathrm{NO}$ removal. The removal is also optimal at $\mathrm{pH}$ around 6-8), avoiding the $\mathrm{pH}(\leq 3.5)$ limitation of $\mathrm{Na}_{2} \mathrm{~S}_{2} \mathrm{O}_{8}-\mathrm{Fe}^{2+}$ only system, the main drawback for Fenton-like systems.

Persulfate is known to be highly reactive at low $\mathrm{pH}(<3)(\mathrm{R} 26-\mathrm{R} 28)$, and also at high $\mathrm{pH}$ (>10) (R24-R25).[21] Khan and Adewuyi (2010) studied the effects of $\mathrm{pH}(\leq 4,7,9$ and 12) on the aqueous PS-only removal of NO at different temperatures $\left(23,50\right.$ and $\left.70^{\circ} \mathrm{C}\right)$. They observed that acidic $\mathrm{pH}$ did not influence the rate of absorption of $\mathrm{NO}$, whereas at $\mathrm{pH} \geq 9$, increased $\mathrm{NO}$ 
conversion occurred at higher temperatures.[17] It was stated that since $O H^{*}$ reacts with NO at almost diffusion controlled rate $\left(k=2 \times 10^{10} M^{-1} s^{-1}\right)(\mathrm{R} 5)$, the consumption of NO in the liquid phase was expected to be much higher at alkaline conditions due to the generation of $\mathrm{OH}^{*}$ (R24) than in an acidic one. However, it was noted that at very high $\mathrm{pH}$, NO removal effectiveness might be reduced due to the rapid dissociation of $\mathrm{OH} \bullet$ in alkaline solutions as illustrated in reaction (R25), where $k_{f}=1.2 \times 10^{10} \mathrm{M}^{-1} \mathrm{~s}^{-1}$ and $k_{b}=9.3 \times 10^{7} \mathrm{~s}^{-1}$ for the forward and backward reaction, respectively, and the oxide radical ion $\left(\mathrm{O}^{*^{-}}\right)$produced is known to react more slowly with the same substrate than $\mathrm{OH}^{*}$. The effects of possible competition for $\mathrm{OH}^{*}$ and $\mathrm{SO}_{4}{ }^{-}$ by the phosphate species in the buffer system used was reported to be insignificant, hence, the impact on persulfate-NOx system was expected to be minimum.[17]

EDTA (ligand denoted by Y) is an amino polycarboxylic acid (APCA) with four carboxylate and two amino groups. It is a weak acid for which the fully protonated acid and fully ionized conjugate base are $\mathrm{H}_{4} \mathrm{Y}$ and $\mathrm{Y}^{-4}$, respectively, and hence, the conjugate base form is significantly affected by the $\mathrm{pH}$ of the solution. With $\mathrm{pH}$ changing, there may be four kinds of Fe-EDTA species: $\mathrm{FeHY}^{-}, \mathrm{FeY}^{-2}, \mathrm{FeY}(\mathrm{OH})^{-3}$, and $\mathrm{FeYOH}^{-4}$, with equilibrium reactions

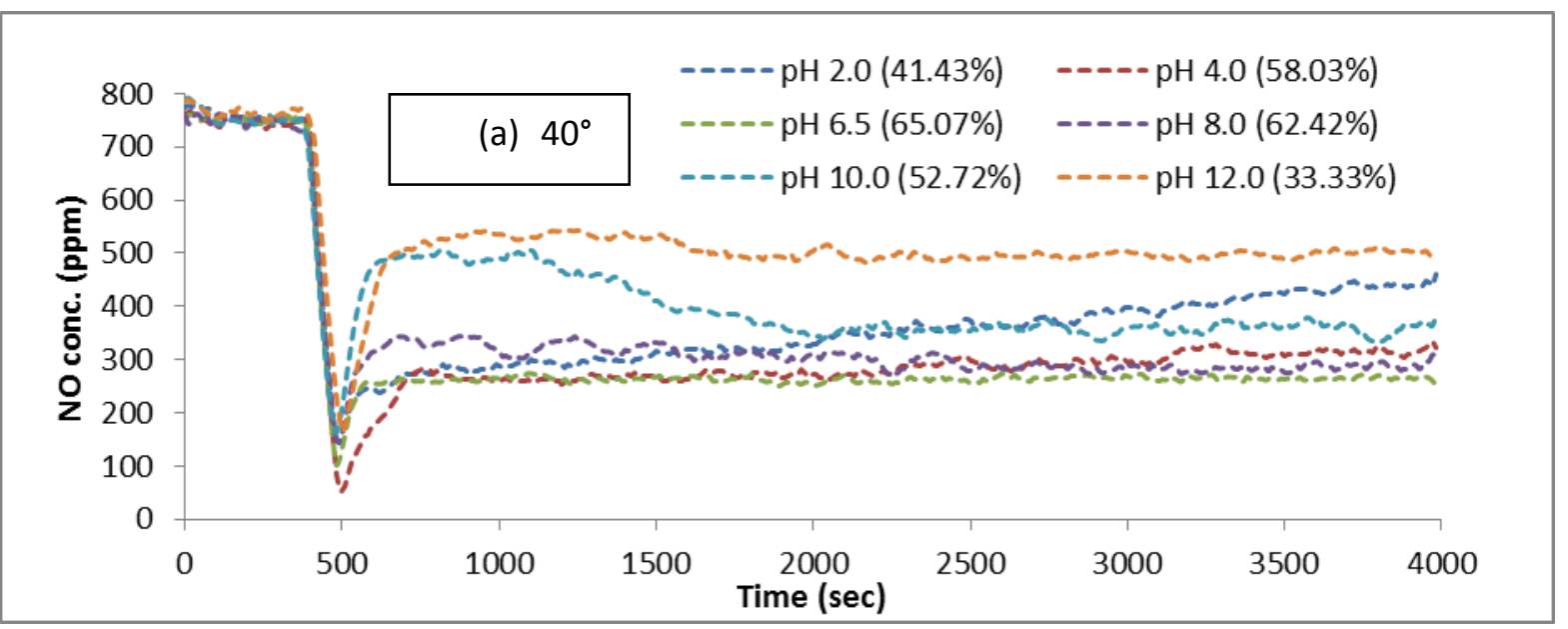



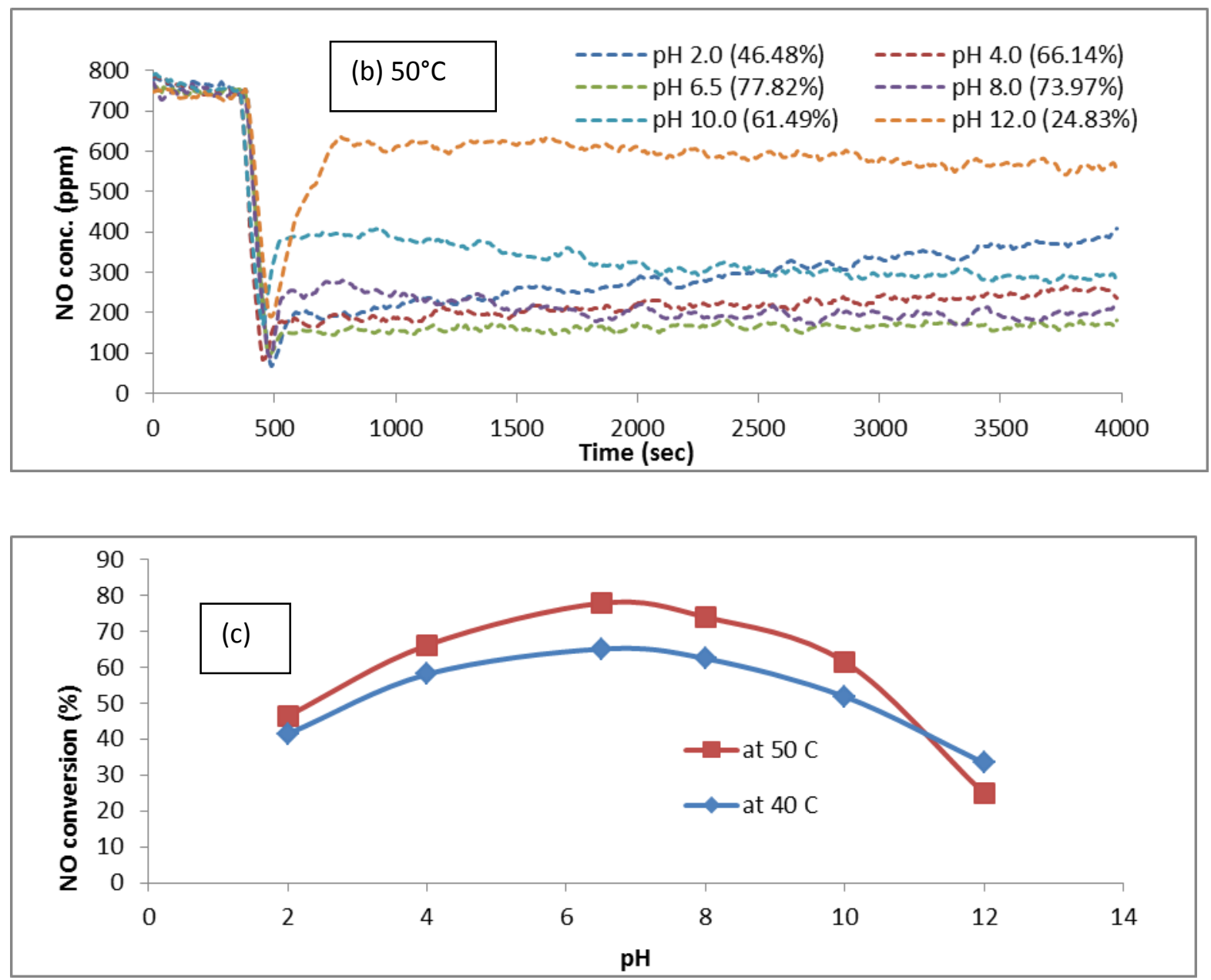

Figure 7. Effects of temperature and $\mathrm{pH}(2-12)$ on $\mathrm{NO}$ removal for the $0.1 \mathrm{M} \mathrm{Na} \mathrm{N}_{2} \mathrm{~S}_{2} \mathrm{O}_{8}$ solution in presence of combined $0.01 M \mathrm{Fe}^{2+}$ and $0.01 \mathrm{M} \mathrm{Na2-EDTA:} \mathrm{(a)} \mathrm{NO} \mathrm{concentration} \mathrm{profiles} \mathrm{at}$ $40{ }^{\circ} \mathrm{C}$, (b) NO concentration profiles at $50{ }^{\circ} \mathrm{C}$, (c) Dependence of NO conversion on $\mathrm{pH}$.

(R43-R47).[42] The formation constants ( $\log \mathrm{K})$ for the various complexation forms of $\mathrm{Fe}^{2+}$ and EDTA have been reported to be 2.8, 14.25, 4.87 and 4.1 at $\mathrm{pH} 1,6,9$, and 10.5, respectively.[45] It can be concluded that the complex formation constant of $\mathrm{Fe}^{2+}$-EDTA reached the largest value at $\mathrm{pH}$ of about 6.0. The effect of $\mathrm{pH}$ value on $\mathrm{NO}$ removal rate for the combined $\mathrm{Na}_{2} \mathrm{~S}_{2} \mathrm{O}_{8}$ and $\mathrm{Fe}^{2+}$-EDTA system can be explained by the impacts of $\mathrm{pH}$ on the complex formation constant of EDTA and ferrous iron. The predominant EDTA species at $\mathrm{pH}=7$ are $\mathrm{H}_{2} \mathrm{Y}^{-2}$ and $\mathrm{HY}^{-3}$. [46] 
Also, the $\mathrm{Fe}^{2+}$-EDTA and $\mathrm{Fe}^{3+}$-EDTA are reported to be the predominant species in the mid-pH range $(\mathrm{pH}>3.8<6.8)$. [45] At more acidic or more alkaline solution, the complex formation constant becomes much smaller. This would explain the optimal and much improved NO removal obtained with the combined $\mathrm{Na}_{2} \mathrm{~S}_{2} \mathrm{O}_{8}$ and $\mathrm{Fe}^{2+}$-EDTA system at $\mathrm{pH}$ around 6.5. The $\mathrm{OH}$ radical is electrophilic in its reactions with acids, and more strongly with amines; its rate of reaction is reduced when the substrate is protonated. The protonation and deprotonation of $\mathrm{N}$ atoms of an APCA bring about a lot of change in the electron density on the molecule, especially the $\alpha$-carbon atom of the acetic acid moiety, thus resulting in a higher rate constant for the deprotonated form.[47, 48] Hobel et al.[42] in 1998, reported its rate constants with EDTA to be $4.0 \times 10^{8} \mathrm{M}^{-1} \mathrm{~s}^{-1}$ at $\mathrm{pH} 4\left(\mathrm{H}_{2} \mathrm{Y}^{2-}\right) ; 2.0 \times 10^{9} \mathrm{M}^{-1} \mathrm{~s}^{-1}$, much faster due to deprotonation, at $\mathrm{pH} 9$ $\left(\mathrm{HY}^{3-}\right)$; and $6.0 \times 10^{9} \mathrm{M}^{-1} \mathrm{~s}^{-1}$ at $\mathrm{pH} 11$ where $\mathrm{Y}^{4-}$ predominates. In addition, Dwibedy et al.[47] in 2000 , reported rate constants of $\mathrm{OH}^{*}$ with acid-base conjugates of EDTA to be $1.8 \times 10^{9}, 1.2 \times$ $10^{9}, 5.0 \times 10^{8}, 3.3 \times 10^{9}$ and $5.7 \times 10^{9} \mathrm{M}^{-1} \mathrm{~s}^{-1}$, respectively, at $\mathrm{pH} 2\left(\mathrm{H}_{4} \mathrm{Y}\right), 3\left(\mathrm{H}_{3} \mathrm{Y}^{-}\right), 5\left(\mathrm{H}_{2} \mathrm{Y}^{2-}\right), 8$ $\left(\mathrm{HY}^{3-}\right)$ and $11\left(\mathrm{Y}^{4-}\right)$. The data also suggest the protonated $\mathrm{Fe}^{3+}$-EDTA and $\mathrm{Fe}^{2+}$-EDTA complexes that predominant in the mid-pH range are less susceptible to $\mathrm{OH}^{*}$ oxidation, which is in consistent with the results in Figure 5 indicating optimal NO removal in the mid-pH range. As stated earlier, reaction (R41) has a large activation energy, hence, the scavenging of $\mathrm{OH}^{*}$ is also more severe at higher temperatures. Therefore, it should be expected that at higher $\mathrm{pH}(>11)$, the combinative effects of $\mathrm{pH}$ and temperature on $\mathrm{OH}^{*}$ depletion should more negatively impact NO removal at $50^{\circ} \mathrm{C}$ than at $40^{\circ} \mathrm{C}$, consistent with Figure $7(\mathrm{c})$.

\subsection{Effects of Initial EDTA Concentrations on Fe Speciation and Material Balance.}

The effects of initial $\mathrm{Na}_{2} \mathrm{EDTA}$ concentrations on iron speciation and material balance for solutions of $0.1 \mathrm{M}$ PS and different $\mathrm{Fe}^{2+}$ concentrations at $50{ }^{\circ} \mathrm{C}$ are summarized in the 
supplementary material (Table S1) as steady state maximum, minimum and average concentration values for the respective species. The concentration profiles are illustrated in Figure 8. Table $\mathrm{S} 1$ also shows the comparison between the concentration of iron species in $\mathrm{Fe}^{2+}$ activated PS system and combined PS and $\mathrm{Fe}^{2+}$-EDTA system at various initial concentrations of $\mathrm{Na}_{2} \operatorname{EDTA}(0-0.02 \mathrm{M})$ and $\mathrm{Fe}^{2+}(0.005-0.02 \mathrm{M})$. The sum of labile $\mathrm{Fe}\left(\mathrm{Fe}^{2+}, \mathrm{Fe}^{3+}\right.$ and $\mathrm{Fe}^{2+}-$ EDTA) measured spectrophotometrically in solution is denoted as total measured Fe. The undetermined $\mathrm{Fe}$ is the difference between initial iron and total measured iron concentrations, and consists of non-labile iron hydroxides, $\mathrm{Fe}^{2+}-\mathrm{EDTA}(\mathrm{NO})$ and other non-labile iron species present in very small amounts. In $\mathrm{PS}_{-} \mathrm{Fe}^{2+}$ system, the undetermined Fe consists of only nonlabile iron species, but in PS-Fe ${ }^{2+}-\mathrm{EDTA}$ systems, undetermined $\mathrm{Fe}$ also consists of $\mathrm{Fe}^{2+}-$ EDTA(NO) and $\mathrm{Fe}^{3+}$-EDTA. The results in Table $\mathrm{S} 1$ reveal that the concentration of $\mathrm{Fe}^{3+}$ in PS$\mathrm{Fe}^{2+}$ systems is almost equal to the sum of the concentration of $\mathrm{Fe}^{3+}$ and $\mathrm{Fe}^{2+}$-EDTA in combined PS-Fe ${ }^{2+}-$ EDTA systems. This would suggest that the addition of EDTA actually formed $\mathrm{Fe}^{2+}-$ EDTA by taking up $\mathrm{Fe}^{2+}$ ion that are supposed to be converted into $\mathrm{Fe}^{3+}$ anyway, thus, the presence of EDTA increases the NO removal without necessarily affecting the PS activation by temperature and $\mathrm{Fe}^{2+}$, further confirming that $\mathrm{Fe}^{2+}$-EDTA does not suppress PS activation. Also, because in the spectrophotometric determination significant amount of $\mathrm{Fe}^{3+}$-EDTA was never found, the difference between undetermined Fe concentration in the two systems is expected to be $\mathrm{Fe}^{2+}$-EDTA(NO), assuming that the concentration of the non-labile iron species remains the same for same initial $\mathrm{Fe}^{2+}$ concentration.

The concentration profiles of $\mathrm{Fe}^{2+}$ is shown in Figure 8(a) and its enlarged form, Figure 8(b), drawn to enhance $\mathrm{Fe}^{2+}$ concentration. It can be seen from Figure 8(a) that $\mathrm{Fe}^{2+}$ concentration remains close to zero throughout the experiment suggesting near complete reaction 
with both PS and EDTA. However, it appears from Figure 8(b) that the use of molar ratio of up to $1: 1$ (generally considered the optimal ratio for $\mathrm{Fe}^{2+}$ and EDTA)[36] does not have a significant effect on the eventual amount of $\mathrm{Fe}^{2+}$ presents in the solution, hence, the beneficial effects on NO removal as observed in Figure 4. Figure 8c shows $\mathrm{Fe}^{3+}$ concentration, which is much lower in PS-Fe ${ }^{2+}$ EDTA systems compared to PS-Fe ${ }^{2+}$ only system. It can be observed from Figure $8 \mathrm{~d}$ showing the $\mathrm{Fe}^{2+}$ EDTA concentration profiles and Table $\mathrm{S} 1$ that, for $0.01 \mathrm{M} \mathrm{Fe}^{2+}$ and $0.005 \mathrm{M}$ EDTA, $20.9 \% \mathrm{Fe}^{2+}$ was converted to $\mathrm{Fe}^{2+} \mathrm{EDTA}$; for $0.01 \mathrm{M} \mathrm{Fe}^{2+}$ and $0.01 \mathrm{M}$ EDTA, $25.5 \%$ $\mathrm{Fe}^{2+}$ was converted to $\mathrm{Fe}^{2+} \mathrm{EDTA}$; and for $0.01 \mathrm{M} \mathrm{Fe}^{2+}$ and $0.02 \mathrm{M}$ EDTA, $28.2 \% \mathrm{Fe}^{2+}$ was converted to $\mathrm{Fe}^{2+}$ EDTA. Increasing initial EDTA converts more $\mathrm{Fe}^{2+}$ to $\mathrm{Fe}^{2+} \mathrm{EDTA}$ but $\mathrm{Fe}^{2+}$ EDTA formation seems to slow down with increasing EDTA concentration. The total labile $\mathrm{Fe}\left(\mathrm{Fe}^{2+}, \mathrm{Fe}^{3+}\right.$ and $\left.\mathrm{Fe}^{2+} \mathrm{EDTA}\right)$ and undetermined $\mathrm{Fe}$ (non-labile species) concentration profiles are illustrated in Figures 8(e) and 8(f), respectively. Although, undetermined Fe concentration increased in PS-Fe ${ }^{2+}$ EDTA systems compared to PS-Fe ${ }^{2+}$ only system, mainly due to the formation of $\mathrm{Fe}^{2+} \mathrm{EDTA}(\mathrm{NO})$ and $\mathrm{Fe}^{3+} \mathrm{EDTA}$, the formation of non-labile species is not significantly dependent on initial EDTA concentration. Because all other non-labile species except $\mathrm{Fe}^{2+}$-EDTA(NO) remain essentially constant throughout the experiment, the increase in the undetermined Fe can be attributed to increase in $\mathrm{Fe}^{2+}$-EDTA(NO) concentration, resulting from the progression of its formation reaction (R20). Also, the slow variation of $\mathrm{Fe}^{2+}-$ EDTA(NO) concentration increases throughout the experiment, suggest that its accumulation in the solution is very small. Therefore, this would indicate its reduction back to $\mathrm{Fe}^{2+}$-EDTA by PS and radicals in the system, thus confirming the synergistic action of PS with $\mathrm{Fe}^{2+}$-EDTA. 

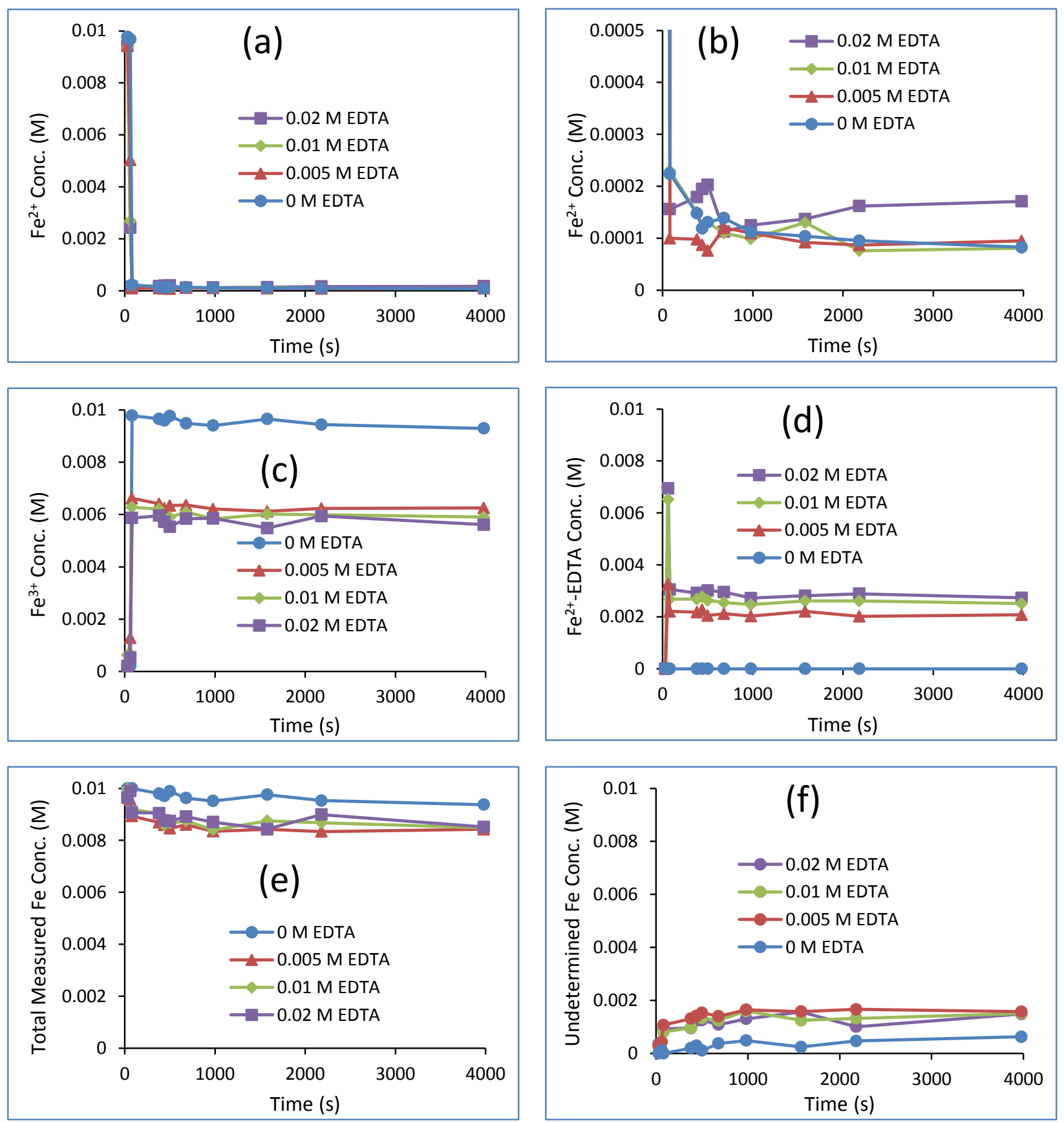

Figure 8. Speciation plots for different iron components for different initial $\mathrm{Na}_{2}$ EDTA concentration

(0.005-0.02 M) with initial $\mathrm{Fe}^{2+}$ concentration of $0.01 \mathrm{M}$ and initial persulfate concentration $0.1 \mathrm{M}$ at 50

${ }^{0} \mathrm{C}$ : (a) $\mathrm{Fe}^{2+}$, (b) Truncated and enlarged $\mathrm{Fe}^{2+}\left(\geq 1000 \mathrm{~s}\right.$ ), (c) Fe ${ }^{3+}$, (d) Fe ${ }^{2+} \mathrm{EDTA}$, (e) Total measured Fe and (f) Undetermined Fe profiles. 


\subsection{Effect of $\mathrm{SO}_{2}$ on NO Removal.}

In general, $\mathrm{Fe}^{2+}$ ions and its complexes promote the interaction between $\mathrm{NO}$ or $\mathrm{HNO}_{2}$ and $\mathrm{HSO}_{3}{ }^{-} / \mathrm{SO}_{3}{ }^{2-}$ via nitrosyl complexes, leading to the formation of hydroxylaminedisulfonate ( $\mathrm{HON}\left(\mathrm{SO}_{3}\right)_{2}{ }^{2-}$ or $\left.\mathrm{HADS}\right)$, sulfamate $\left(\mathrm{H}_{2} \mathrm{~N}\left(\mathrm{SO}_{3}\right)^{-}, \mathrm{N}_{2} \mathrm{O}\right.$ and $\mathrm{HSO}_{4}^{-}$, and is accompanied by the oxidation of $\mathrm{Fe}^{2+}$ to $\mathrm{Fe}^{3+}$. Completion of the catalytic cycle occurs spontaneously in the presence $\mathrm{HSO}^{3-} / \mathrm{SO}_{3}{ }^{2-} \cdot[39,49] \mathrm{An}$ important consideration in the removal of $\mathrm{NO}$ with iron chelates in WFGD scrubber system is the ability of the nitrosyl complexes to regenerate the metal chelates by reacting with absorbed $\mathrm{SO}_{2}$ and $\mathrm{S}(\mathrm{IV})$ species. Sada et al. demonstrated that the absorption rate of $\mathrm{NO}$ in the presence of $\mathrm{SO}_{2}$ exceeded that in the absence of $\mathrm{SO}_{2}$, and the absorption enhancement was attributed to the following reactions.[29, 30]

$$
\begin{aligned}
& \mathrm{Fe}^{2+} \mathrm{EDTA}+\mathrm{NO} \leftrightarrow \mathrm{Fe}^{2+} \mathrm{EDTA}(\mathrm{NO}) \\
& 4 \mathrm{Fe}^{2+} \mathrm{EDTA}(\mathrm{NO})+4 \mathrm{HSO}_{3}^{-} \rightarrow 4 \mathrm{Fe}^{2+} \mathrm{EDTA}+2 \mathrm{HON}\left(\mathrm{SO}_{3}\right)_{2}^{2-}+\mathrm{H}_{2} \mathrm{~N}_{2} \mathrm{O}_{2} \\
& \mathrm{Fe}^{2+} \mathrm{EDTA}+\mathrm{SO}_{3}^{2-} \leftrightarrow \mathrm{Fe}^{2+} \mathrm{EDTA}\left(\mathrm{SO}_{3}\right)^{2-} \\
& \mathrm{Fe}^{2+} \mathrm{EDTA}\left(\mathrm{SO}_{3}\right)^{2-}+\mathrm{NO} \leftrightarrow \mathrm{Fe}^{2+} \mathrm{EDTA}\left(\mathrm{SO}_{3}\right)^{2-}(\mathrm{NO}) \\
& \mathrm{Fe}^{2+} \mathrm{EDTA}\left(\mathrm{SO}_{3}\right)^{2-}(\mathrm{NO})+\mathrm{SO}_{2}+\mathrm{H}_{2} \mathrm{O} \rightarrow \mathrm{Fe}^{2+} \mathrm{EDTA}(\mathrm{NO})+2 \mathrm{HSO}_{3}^{-} \\
& \mathrm{Fe}^{3+} \mathrm{EDTA}+\mathrm{HSO}_{3}^{-} \rightarrow \mathrm{Fe}^{2+} \mathrm{EDTA}^{2+} 0.5 \mathrm{~S}_{2} \mathrm{O}_{6}^{2-}+\mathrm{H}^{+} \\
& 2 \mathrm{Fe}^{2+} \mathrm{EDTA}(\mathrm{NO})+\mathrm{SO}_{3}^{2-} \rightarrow 2 \mathrm{Fe}^{2+} \mathrm{EDTA}+\mathrm{SO}_{3}(\mathrm{NO})_{2}^{2-} \\
& \rightarrow 2 \mathrm{Fe}^{3+} \mathrm{EDTA}+\mathrm{N}_{2} \mathrm{O}_{2}^{2-}+\mathrm{SO}_{3}^{2-}
\end{aligned}
$$

where eq 5 and eq 9 both show the regeneration of $\mathrm{Fe}^{2+} \mathrm{EDTA}$ through reduction by $\mathrm{HSO}_{3}^{-}, \mathrm{H}_{2} \mathrm{~N}_{2} \mathrm{O}_{2}$ further decomposes to $\mathrm{N}_{2} \mathrm{O}$ and $\mathrm{H}_{2} \mathrm{O}$ above $\mathrm{pH}>7.5$, and $\mathrm{N}_{2} \mathrm{O}_{2}^{2-}$ reacts with $\mathrm{H}_{2} \mathrm{O}$ to produce $\mathrm{N}_{2} \mathrm{O}$ (plus $2 \mathrm{OH}^{-}$). The $\mathrm{Fe}^{3+}$-EDTA is also reduced by $\mathrm{HSO}_{3}{ }^{-}$to produce $\mathrm{Fe}^{2+}$ and EDTA as shown in reactions (R48-R50). The oxidation of S(IV) by $\mathrm{OH}^{*}, \mathrm{SO}_{4}^{--}$and $\mathrm{S}_{2} \mathrm{O}_{8}^{2-}$ have 
been discussed in details elsewhere.[18] $\mathrm{N}_{2} \mathrm{O}$ usually forms in strong acid solutions, but which in $\mathrm{O}_{2}$-deficient solutions reacts with $\mathrm{H}_{2} \mathrm{O}$ to form $\mathrm{N}_{2}$ and $\mathrm{HNO}_{2}$ (that is subsequently oxidized to $\left.\mathrm{HNO}_{3}\right)(\mathrm{R} 39) \cdot[25,50,51]$

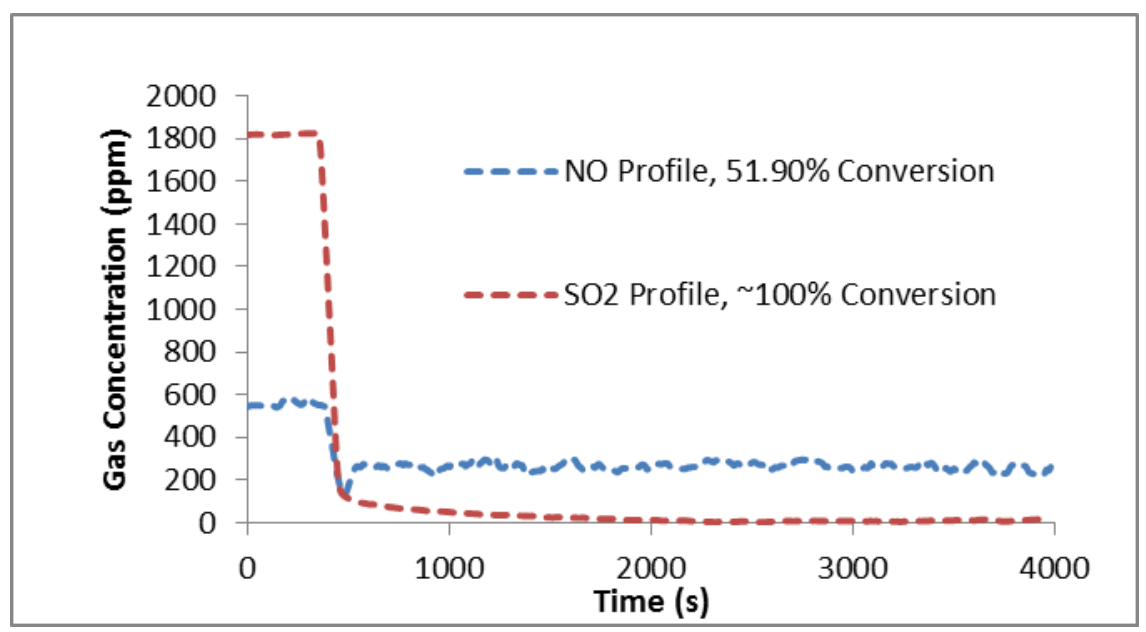

Figure 9. Concentration profiles for the simultaneous removal of $\mathrm{NO}$ and $\mathrm{SO}_{2}$ at $30{ }^{\circ} \mathrm{C}$ for $0.1 \mathrm{M}$ $\mathrm{Na}_{2} \mathrm{~S}_{2} \mathrm{O}_{8}$ solution in the presence of combined $0.01 \mathrm{M} \mathrm{Fe}^{2+}$ and $0.01 \mathrm{M} \mathrm{Na2-EDTA}$.

We have preliminarily investigated the effect of $\mathrm{SO}_{2}(1800 \mathrm{ppm})$ on $\mathrm{NO}(550 \mathrm{ppm})$ removal in $0.1 \mathrm{M} \mathrm{PS}$ and $0.01 \mathrm{M} \mathrm{Fe}^{2+}$-EDTA solution at $30^{\circ} \mathrm{C}$, and the result is shown in Figure 9. It appears that the presence of $\mathrm{SO}_{2}$ does not significantly affect $\mathrm{NO}$ removal efficiency (even with a feed ratio of over 3:1 $\mathrm{SO}_{2}$ and $\mathrm{NO}$ ) compared with the case without $\mathrm{SO}_{2}$ (51.9 vs. 55.6), while $\mathrm{SO}_{2}$ itself is completely removed. In our prior studies using PS-only solution and a flue gas

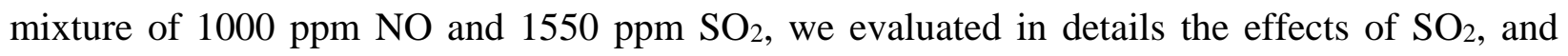
observed $\mathrm{SO}_{2}$ significantly enhanced $\mathrm{NO}$ removal in the complex reacting system, especially in the $\mathrm{pH}$ range of 6.5-8.5.[18] The slight increase observed in this study in the presence of a large amount of $\mathrm{SO}_{2}$ is likely due to the combinative effects of $\mathrm{SO}_{2}$ and EDTA enhancement of NO removal, and the competition of $\mathrm{NO}$ and $\mathrm{SO}_{2}$ for available oxidants. Also, using aqueous PMS 
and flue gas containing $\mathrm{NO}, \mathrm{SO}_{2}$ and $\mathrm{CO}_{2}$, we previously showed that $5-10 \% \mathrm{CO}_{2}$ had no significant effects on NO removal.[10]

3.6 Relevance of this study to energy and the application of the process. It is evident from the results of this work that the PS-Fe ${ }^{2+}$ EDTA process offers enough incentive for utilization in the simultaneous control of $\mathrm{NO}_{\mathrm{x}}$ and $\mathrm{SO}_{2}$ from oil- and coal-fired power plants, incinerators, and industrial emission sources. The best conditions for chemical reactions of $\mathrm{NO}_{\mathrm{x}}$ are indicated in this paper. In addition to its enhanced reactivity, this process appears to demonstrate the feasibility of sustained longtime high NO absorption capability at relatively lower temperatures, resulting in reduced energy usage. This higher removal should provide a remarkable advantage in the cleanup of industrial flue gas, which is generally received at the treatment plant in the temperature range of $50-70{ }^{\circ} \mathrm{C}$. Also, Liu and coworkers (2014) noted that boiler flue gas contains large amounts of waste heat and the temperature is often more than 120 ${ }^{\circ} \mathrm{C}$, and suggested that this reservoir of waste heat from the boiler can completely provide the energy needed for thermal persulfate activation.[15] On the basis of the results, it appears that very high concentrations of $\mathrm{NO}$ and $\mathrm{SO}_{2}$ can be simultaneously and effectively scrubbed from the flue gas by proper balance of PS and EDTA concentrations, and process temperature and $\mathrm{pH}$. Generally, in the removal of NO with iron chelates, the nitrosyl complexes (i.e., nitrogen-sulfur or N-S compounds or intermediates such as sulfamate and amine sulfonate), formed from interaction between nitrite and bisulfate, are usually treated or converted to useful products. In addition, an important aspect of this process is the ability of nitrosyl complexes to regenerate the metal chelate in the scrubber system with simultaneous production of sulfate and nitrogen species such as $\mathrm{N}_{2}$. In addition, the complex $\mathrm{Fe}^{2+}$-EDTA(NO) can be decomposed to regenerate $\mathrm{Fe}^{2+}$-EDTA and recover NO as a rich gas.[25] The progress in liquid treatment is expected to 
promote the application of wet scrubbing using $\mathrm{Fe}^{2+}$-EDTA, making the PS-Fe ${ }^{2+}$-EDTA a promising solution to multicomponent gas cleanup.

The approach used in this study is appropriate for relatively small-scale operations involving limited volumes of waste, which provide sufficient residence times in the scrubber for $\mathrm{NO}_{\mathrm{x}}$ to dissolve and react with chemicals in the scrubbing solutions. For example, there are over 650,000 small and medium size coal-fired boilers, industrial furnaces and refuse incinerators in China alone, where the proposed wet process for the simultaneous treatment of $\mathrm{NO}_{\mathrm{x}}$ and $\mathrm{SO}_{2}$ could have great prospect for potential practical applications.[15] The bubble column reactor is useful for laboratory investigations. The scale-up of small-scale bubble columns such as the ones used in this study to large-scale units is straightforward and is presented in detail elsewhere.[9] Contact times for commercial bubble columns and packed columns range from 0.01 to 1.0 s.[10] This technology might also be applicable as an emergency system when the ordinary deNOx system is out of order or in chemical industries where the gas flow rates are normally smaller than those from oil- and coal-fired power plants. We also see this approach is desirable for small operations that wish to obviate the need to install additional costly control equipment or have limited space to build a new $\mathrm{SO}_{2}$ scrubber and an SCR system for $\mathrm{NO}_{\mathrm{x}}$ control. Hence, the development of the innovative $\mathrm{Na}_{2} \mathrm{~S}_{2} \mathrm{O}_{8}-\mathrm{Fe}^{2+}$-EDTA technology would be timely given the need for continuous use of coal as a source of electric energy. This study is expected to be useful for its scaling-up in the future in pilot plant tests to better demonstrate the potential applications and cost benefits of this process.

However, the current study also indicates a number of areas in which additional research is needed. These include a more detailed study on the effects of $\mathrm{SO}_{2}$ and other flue gas constituents $\left(\mathrm{O}_{2}, \quad \mathrm{CO}_{2}\right)$; mass-transfer reaction kinetics; the determination of 
intermediates/products for a more comprehensive material balance; and modeling. For example, flue gases typically contain 2-15\% $\mathrm{O}_{2}$ resulting from excess air introduced into the fossil fuel combustion system to ensure $\mathrm{O}_{2}$ to fully consume the fuel. As noted earlier, $\mathrm{O}_{2}$ in the flue gas continuously oxidizes the $\mathrm{Fe}^{2+}$ in the coordinated EDTA during the NO absorption process by $\mathrm{Fe}^{2+}$-EDTA, producing the ferric complex, which is does not react with $\mathrm{NO}$, by reaction in eq $11[36]$

$4 \mathrm{Fe}^{2+}-\mathrm{EDTA}+\mathrm{O}_{2}+2 \mathrm{H}_{2} \mathrm{O} \stackrel{k_{21}}{\longrightarrow} 4 \mathrm{Fe}^{3+}-\mathrm{EDTA}+4 \mathrm{OH}^{-}$

$\mathrm{k}_{19}=1.09 \times 10^{4} \mathrm{e}^{\left(-\frac{2.33 \times 10^{4}}{\mathrm{RT}}\right)}$

On the other hand, it has been suggested that $\mathrm{NO}_{2}^{-}$as could react $\mathrm{Fe}^{3+}$-EDTA serving as an electron donor back to $\mathrm{Fe}^{2+}$-EDTA as in reaction (R29), aiding iron recycling.[25, 38] However, as noted by several investigators, the oxidation kinetics of $\mathrm{Fe}^{2+}$-EDTA by dissolved oxygen is complex.[52-54] Therefore, its role in the PS-NO-SO2-Fe-EDTA system will require a more thorough evaluation, which is beyond the scope of the current investigation.

\section{Conclusion}

The effects of initial concentrations of PS and EDTA at different temperatures and $\mathrm{pH}$ levels on the removal of $\mathrm{NO}$ from simulated flue gas is investigated using combined aqueous $\mathrm{Na}_{2} \mathrm{~S}_{2} \mathrm{O}_{8}$ and $\mathrm{Fe}^{2+}$-EDTA solutions in a bubble column reactor. The experiments were conducted in the temperature and $\mathrm{pH}$ ranges of $23-70{ }^{\circ} \mathrm{C}$ and $2-12$, respectively, using $0.05,0.10$ and 0.20 $\mathrm{M} \mathrm{Na}_{2} \mathrm{~S}_{2} \mathrm{O}_{8}$ and $0.01 \mathrm{Fe}^{2+}$ in the absence and presence of $0.005,0.01,0.02$, and $0.05 \mathrm{M} \mathrm{Na} 2-$ EDTA. The effect of $\mathrm{SO}_{2}$ was also preliminarily studied. Increased temperature led to an increased fractional conversion of NO (percent of inlet NO removed) at all persulfate levels, with the increases almost linear with temperature. On the other hand, high concentration of EDTA was not useful with increasing temperature. With $0.10 \mathrm{M} \mathrm{Na}_{2} \mathrm{~S}_{2} \mathrm{O}_{8}, 0.01 \mathrm{Fe}^{2+}$ and EDTA 
concentration of $\leq 0.01 \mathrm{M}$, NO conversion increases with temperature from 23 to $70{ }^{\circ} \mathrm{C}$, with the rate highest for 0.01 M EDTA concentration. However, with $0.02 \mathrm{M}$ EDTA, NO conversion deteriorates rapidly at $60{ }^{\circ} \mathrm{C}$, and with $0.05 \mathrm{M}$ EDTA, the rapid deterioration started even earlier at $30{ }^{\circ} \mathrm{C}$. At $70^{\circ} \mathrm{C}$, NO conversion increases from 83.40 to $96.28 \%$ with EDTA concentration from 0.005 to $0.01 \mathrm{M}$ EDTA but decreases to $29.22 \%$ with $0.02 \mathrm{M}$ EDTA, and to $0.4 \%$ with $0.05 \mathrm{M}$ EDTA, compared to about $69 \%$ in the absence of EDTA. The results at temperatures of 40 and $50{ }^{\circ} \mathrm{C}$ indicate that the process operates at an optimal $\mathrm{NO}$ removal in the $\mathrm{pH}$ of $6-8$ with efficiency decreasing at very low or high $\mathrm{pH}$. Better NO removal was obtained at the temperature of $50{ }^{\circ} \mathrm{C}$ compared to $40{ }^{\circ} \mathrm{C}$ except at the highest $\mathrm{pH}$ of 12 , where the removal is higher at $40{ }^{\circ} \mathrm{C}$.

\section{Acknowledgments}

The authors wish to acknowledge the contribution of National Science Foundation (NSF) for the funding received via Grant CBET-0651811.

\section{References}

[1] Power Plants, Pollution and Soot - Air Quality, Environmental Defense Fund: New York. <http://www.edf.page.cfm?tagID-78> (accessed May 20, 2010).

[2] National Energy Technolgy Lab (NETL). Advanced $\mathrm{NO}_{\mathrm{x}}$ emissions control: Regulatory drivers. NETL, Pittsburgh, PA 2010. <http://www.netl.doe.gov/> (accessed June 11, 2010).

[3] Baranski, P.E., Underwood, B. Mitigate Air pollution with catalytic technology. Chem. Eng. Prog. June 1014, 30 - 34.

[4] Yu, H., Tan, Z, The, J. Recent advances in simultaneous desulfurization \& denitrification. Air \& Waste Manage. Assoc. (EM), Dec 2014, 30 - 34.

[5] Sweeney A,J., Liu Y.A. Use of simulation to optimize $\mathrm{NO}_{\mathrm{x}}$ abatement by absorption and selective catalytic reduction. Ind. Eng. Chem. Res. 2001, 40:2618 -2627. 
[6] Rezaei F., Rownaghi A.A., Monjezi S., Lively R.P., Jones CW. SO $\mathrm{NO}_{\mathrm{x}}$ Removal from flue gas streams by solid adsorbents: A review of current challenges and future directions. Energy Fuels 2015;29:5467 - 5486.

[7] Hutson N.D., Krzyzynska R., Srivastava R.K. Simultaneous removal of $\mathrm{SO}_{2}, \mathrm{NO}_{\mathrm{x}}$, and $\mathrm{Hg}$ from coal flue gas using a $\mathrm{NaClO}_{2}$-enhanced wet scrubber. Ind. Eng. Chem. Res. 2008; 47, 5825 -5831.

[8] Zheng C., Xu C., Zhang Y., Zhang J., Gao X., Luo Z., et al. Nitrogen oxide absorption and nitrite/nitrate formation in limestone slurry for WFGD system. Applied Energy 2014,129, 187-194.

[9] Adewuyi Y, He X, Shaw H, Lolertpihop W. Simultaneous absorption and oxidation of NO and $\mathrm{SO}_{2}$ by aqueous solutions of sodium chlorite. Chem. Eng. Commun. 1999, 174:21-51

[10] Adewuyi Y.G,; Owusu S.O. Aqueous Absorption and oxidation of nitric oxide with oxone for the treatment of tail gases: Process feasibility, stoichiometry, reaction pathways, and absorption rate. Ind. Eng. Chem. Res. 2003, 42, 4084-4100.

[11] Demmink J.F.; van Gils I.C.F.; Beenackers A.A.C.M. Absorption of nitric oxide into aqueous solutions of ferrous chelates accompanied by instantaneous reaction. Ind. Eng. Chem. Res. 1997, 36, 4914-4927.

[12] Liu, Y.; Zhang, J,; Pan, J.; Tang, A. Investigation on the removal of NO from $\mathrm{SO}_{2}$-containing simulated flue gas by an ultraviolet/Fenton-like reaction. Energy \& Fuels 2012, 26, 5430-5436.

[13] Liu, Y.X.; Zhang, J. Photochemical oxidation removal of $\mathrm{NO}$ and $\mathrm{SO}_{2}$ from simulated flue gas of Coal-Fired Power Plants by Wet Scrubbing Using UV/H2O2 Advanced Oxidation Process. Ind. Engin. Chem. Res. 2011, 50, 3836-3841

[14] Liu, Y., Zhang, J.; Sheng C.; Zhang, Y.; Zhao L. Simultaneous removal of NO and $\mathrm{SO}_{2}$ from coal-fired flue gas by $\mathrm{UV} / \mathrm{H}_{2} \mathrm{O}_{2}$ advanced oxidation process. Chem. Eng. J. 2010, 162, 1006-1011.

[15] Liu, Y.; Wang, Q. Removal of elemental mercury from flue gas by thermally activated ammonium persulfate in a bubble column reactor. Environ. Sci. Technol. 2014, 48, 12181- 12189.

[16] Chang S.G.; Littlejohn, D.; Lynn, S. Effects of metal chelates on wet flue gas scrubbing chemistry. Environ. Sci. Technol. 1983, 17, 649-653. 
[17] Khan, N.E.; Adewuyi, Y.G. Absorption and oxidation of nitric oxide (NO) by aqueous solutions of sodium persulfate in a bubble column reactor. Ind. Eng. Chem. Res. 2010, 49, 8749-8760..

[18] Adewuyi, Y.G.; Sakyi, N.Y. Simultaneous absorption and oxidation of nitric oxide and sulfur dioxide by aqueous solutions of sodium persulfate activated by temperature. Ind. Engin. Chem. Res. 2013, 52, 11702-11711.

[19] Adewuyi, Y.G.; Sakyi, N.Y. Removal of nitric oxide by aqueous sodium persulfate simultaneously activated by temperature and $\mathrm{Fe}^{2+}$ in a lab-scale bubble reactor. Ind. Engin. Chem. Res. $2013,52,14687-14697$.

[20] Adewuyi Y.G.; Khan, M.A.; Sakyi, N.Y. Kinetics and modeling of the removal of nitric Oxide by aqueous sodium persulfate simultaneously activated by temperature and $\mathrm{Fe}^{2+}$. Ind. Engin. Chem. Res. 2014, 53, 828-839.

[21] House D.A. Kinetics and mechanism of oxidations by peroxydisulfate. Chem. Rev. 1962, 62, 185-203.

[22] Wardman P. Reduction potentials of one-electron couples involving free-radicals in aqeusous solution. J. Phys. Chem. Ref. Data 1989, 18, 1637-1755.

[23] Adewuyi, Y.G. Sonochemistry in environmental remediation. 1. Combinative and hybrid sonophotochemical oxidation processes for the treatment of pollutants in water. Environ. Sci. Technol. 2005, 39:3409-3420.

[24] Adewuyi YG. Sonochemistry in environmental remediation. 2. Heterogeneous sonophotocatalytic oxidation processes for the treatment of pollutants in water. Environ. Sci. Technol. 2005, 39, 8557-8570.

[25] Adewuyi, Y.G.; Khan, M.A. Nitric oxide removal by combined persulfate and ferrous-EDTA reaction systems. Chem. Eng. J. 2015, 281, 575-587.

[26] The Interstate Technology and Regulatory Council (ITRC). Technical and Regulatory for in situ Chemical Oxidation of Contaminated Soil and Groundwater, second ed. The Interstate Technology and Regulatory Council, Washington, DC, 2005. <http://www.itrcweb.org/> 
[27] Buxton, G.V.; Malone T.N.; Salmon G.A. Reaction of $\mathrm{SO}_{4}{ }^{-}$with $\mathrm{Fe}^{2+}, \mathrm{Mn}^{2+}$ and $\mathrm{Cu}^{2+}$ in aqueous solution. J. Chem. Soc. Faraday Trans. 1997, 93, 2893-2897.

[28] Suchecki, T.T; Mathews, B.; Kumazawa, H. Kinetic study of ambient-temperature reduction of Fe(III)edta by $\mathrm{Na}_{2} \mathrm{~S}_{2} \mathrm{O}_{4}$. Ind. Eng. Chem. Res. 2005, 44, 4249-4253.

[29] Sada, E.; Kumazawa, H.; Kudo, I.; Kondo, T. Individual and simultaneous absorption of dilute $\mathrm{NO}$ and $\mathrm{SO}_{2}$ in aqueous slurries of $\mathrm{MgSO}_{3}$ with Fe(II)-EDTA. Ind. Eng. Chem. Proc. Des. Develop. 1980, $19,377-382$.

[30] Sada E.; Kumazawa H.; Hikosaka, H. A kinetic study of absorption of nitrogen oxide (NO) into aqueous solutions of sodium sulfite with added iron(II)-EDTA chelate. Ind. Eng. Chem. Fundtls. 1986, 25, 386-390.

[31] Yu, H., Zhu, Q.; Tan, Z. Absorption of nitric oxide from simulated flue gas using different absorbents at room temperature and atmospheric pressure. Appl. Energy; 2012, 93, 53-58.

[32] Jethani, K.R.; Suchak, N.J.; Joshi, J.B. Selection of reactive solvent for pollution abatement of $\mathrm{NO}_{x}$. Gas Sep. Purif. 1990, 4, 8-28.

[33] Liang, C.; Bruell, C.J.; Marley, M.C.; Sperry, K.L. Persulfate oxidation for in situ remediation of TCE. II. Activated by chelated ferrous ion. Chemosphere; 2004, 55, 1225-1233.

[34] Khan, N.E; Adewuyi, Y.G. A new method of analysis of peroxydisulfate using ion chromatography and its application to the simultaneous determination of peroxydisulfate and other common inorganic ions in a peroxydisulfate matrix. J. Chromatogr. A. 2011, 1218, 392-397.

[35] Kolthoff, I.; Miller, I. The chemistry of persulfate. I. The kinetics and mechanism of the decomposition of the persulfate ion in aqueous medium. J. Am. Chem. Soc. 1951, 73, 3055-3059.

[36] Liu N, Lu B-H, Zhang S-H, Jiang J-L, Cai L-L, Li W, et al. Evaluation of Nitric Oxide Removal from Simulated Flue Gas by Fe(II)EDTA/Fe(II)citrate Mixed Absorbents. Energy Fuels 2012, 26, 49104916.

[37] Wang, L; Zhao, W.; Wu, Z. Simultaneous absorption of $\mathrm{NO}$ and $\mathrm{SO}_{2}$ by $\mathrm{Fe}(\mathrm{II}) \mathrm{EDTA}$ combined with $\mathrm{Na}_{2} \mathrm{SO}_{3}$ solution. Chem. Eng. J. 2007, 132, 227-232. 
[38] Jaworska, M.; Stopa, G.; Stasicka, Z. Photochemical NO-removal and $\mathrm{NO}_{\mathrm{x}}$-release in the presence of Fe-EDTA complexes. DFT calculations of electronic structure and spectroscopy of the $[\mathrm{Fe}(\mathrm{edta})(\mathrm{NO})]^{2-}$ complex. Nitric Oxide 2010, 23, 227-233.

[39] Chang SG. Technical analyses of a wet process for flue gas simultaneous desulfurization and denitrification. In Fossil Fuels Utilization, Amer. Chem. Soc.; 1986; Vol. 319, pp 159-175.

[40] Brandt, C.; van Eldik, R. Transition metal-catalyzed oxidation of sulfur (IV) oxides. Atmospheric-relevant processes and mechanisms. Chem. Rev. 1995, 95,119-190.

[41] Lati, J.; Meyerstein, D. Oxidation of first-row bivalent transition-metal complexes containing ethylenediaminetetra-acetate and nitrilotriacetate ligands by free radicals: a pulse-radiolysis study. J. Chem. Soc. Dalton Trans. 1978, 1105-1118.

[42] Hobel, B,; von Sonntag, C. OH-radical induced degradation of ethylenediaminetetraacetic acid (EDTA) in aqueous solution: a pulse radiolysis study. J. Chem. Soc. Perkin Trans. 2. 1998, 509=514.

[43] Buxton, G; Greenstock, C; Helman, W; Ross, A. Critical review of rate constants for reactions of hydrated electrons, hydrogen atoms and hydroxyl $\operatorname{radicals}(\bullet \mathrm{OH} / \bullet \mathrm{O})$ in aqueous solution. J. Phys. Chem. Ref. Data 1988;17:513-886.

[44] Sillanpää, M.E.T; Kurniawan A.T; Lo W-H. Degradation of chelating agents in aqueous solution using advanced oxidation process (AOP). Chemosphere. 2011, 83, 1443-1460.

[45] Shimizu, K.; Hutcheson, R; Engelmann, M.D.; Cheng, F.I. Cyclic voltammetric and aqueous equilibria model study of the $\mathrm{pH}$ dependant iron(II/III)ethylenediamminetetraacetate complex reduction potential. J. Electroanal. Chem. 2007, 603, 44-50.

[46] Frim J.A.; Rathman, J.F.; Weavers L.K. Sonochemical destruction of free and metal-binding ethylenediaminetetraacetic acid. Water Res. 2003, 37, 3155=3163.

[47] Dwibedy, P,; Dey, GR; Naik, D.B; Kishore, K. Rate constants for the reaction of OH radicals with some amino polycarboxylic acids. International J. Chem. Kinet. 2000. 32, 99-104.

[48] Motekaitis, R.J; Cox, X.B.; Taylor P.; Martell A.E.; Miles, B; Tvedt Jr. T.J. Thermal degradation of EDTA chelates in aqueous solution. Can. J. Chem. 1982, 60, 1207-1213. 
[49] Turšič J.; Grgić I.; Bizjak, M. Influence of $\mathrm{NO}_{2}$ and dissolved iron on the $\mathrm{S}(\mathrm{IV})$ oxidation in synthetic aqueous solution. Atmos. Environ. 2001, 35, 97-104.

[50] Littlejohn, D; Chang, S.G. Reaction of ferrous chelate nitrosyl complexes with sulfite and bisulfite ions. Ind. Eng. Chem. Res. 1990, 29, 10-14.

[51] Littlejohn, D.; Chang, S.G. Kinetic study of ferrous nitrosyl complexes. J. Phys. Chem. 1982, 86, 537-540.

[52] Sada, E.; Kumazawa, H.; Machida, H. Oxidation kinetics of Fe(II)-EDTA and Fe(II)-NTA chelates by dissolved oxygen. Ind. Eng. Chem. Res. 1987, 26, 1468-1472.

[53] Wubs HJ.; Beenackers, A.A.C.M. Kinetics of the oxidation of ferrous chelates of EDTA and HEDTA in aqueous solution. Ind. Eng. Chem. Res. 1993, 32, 2580-2594.

[54] Zang, V; Van Eldik, R. Kinetics and mechanism of the autoxidation of iron(II) induced through chelation by ethylenediaminetetraacetate and related ligands. Inorg. Chem. 1990, 29, 1705-1711..

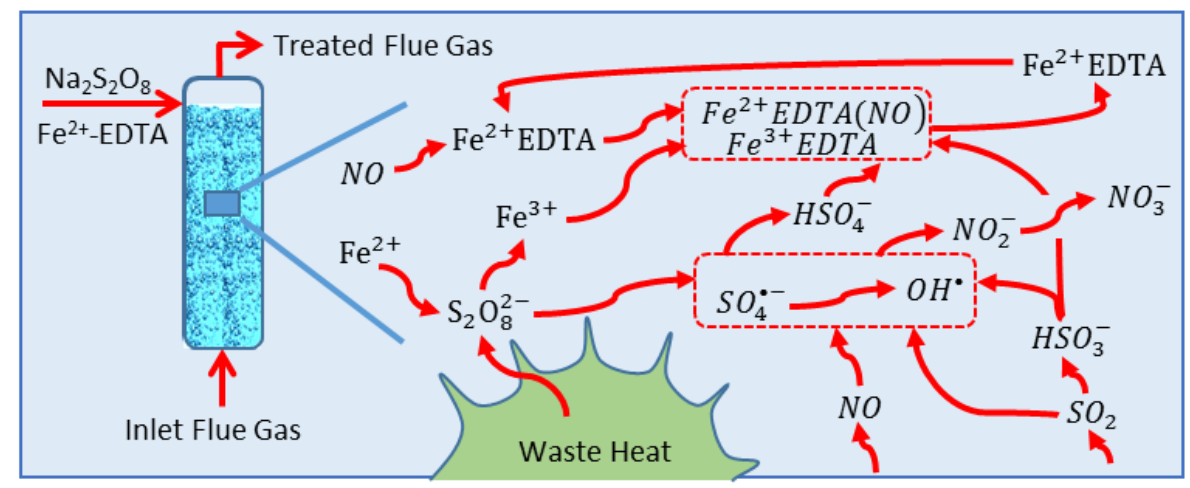

\section{Graphical Abstract}

